\title{
Mitochondria: Insights into Crucial Features to Overcome Cancer Chemoresistance
}

\author{
Ilaria Genovese ${ }^{1}$ (D), Marianna Carinci ${ }^{1}$, Lorenzo Modesti ${ }^{1}$, Gianluca Aguiari ${ }^{2}$, Paolo Pinton ${ }^{1}$ (D) \\ and Carlotta Giorgi ${ }^{1, *}$
}

1 Department of Medical Sciences, Section of Experimental Medicine, University of Ferrara, 44121 Ferrara, Italy; ilaria.genovese@unife.it (I.G.); marianna.carinci@unife.it (M.C.); lorenzo.modesti@unife.it (L.M.); paolo.pinton@unife.it (P.P.)

2 Department of Neuroscience and Rehabilitation, Section of Biochemistry, Molecular Biology and Genetics, University of Ferrara, 44121 Ferrara, Italy; gianluca.aguiari@unife.it

* Correspondence: carlotta.giorgi@unife.it

Citation: Genovese, I.; Carinci, M.; Modesti, L.; Aguiari, G.; Pinton, P.; Giorgi, C. Mitochondria: Insights into Crucial Features to Overcome Cancer Chemoresistance. Int. J. Mol. Sci. 2021, 22, 4770. https://doi.org/ $10.3390 /$ ijms 22094770

Academic Editors: Yong Teng, Amadou K. S. Camara and Xin Qi

Received: 28 March 2021

Accepted: 27 April 2021

Published: 30 April 2021

Publisher's Note: MDPI stays neutral with regard to jurisdictional claims in published maps and institutional affiliations.

Copyright: (c) 2021 by the authors. Licensee MDPI, Basel, Switzerland. This article is an open access article distributed under the terms and conditions of the Creative Commons Attribution (CC BY) license (https:// creativecommons.org/licenses/by/ $4.0 /)$.

\begin{abstract}
Mitochondria are key regulators of cell survival and are involved in a plethora of mechanisms, such as metabolism, $\mathrm{Ca}^{2+}$ signaling, reactive oxygen species (ROS) production, mitophagy and mitochondrial transfer, fusion, and fission (known as mitochondrial dynamics). The tuning of these processes in pathophysiological conditions is fundamental to the balance between cell death and survival. Indeed, ROS overproduction and mitochondrial $\mathrm{Ca}^{2+}$ overload are linked to the induction of apoptosis, while the impairment of mitochondrial dynamics and metabolism can have a double-faceted role in the decision between cell survival and death. Tumorigenesis involves an intricate series of cellular impairments not yet completely clarified, and a further level of complexity is added by the onset of apoptosis resistance mechanisms in cancer cells. In the majority of cases, cancer relapse or lack of responsiveness is related to the emergence of chemoresistance, which may be due to the cooperation of several cellular protection mechanisms, often mitochondria-related. With this review, we aim to critically report the current evidence on the relationship between mitochondria and cancer chemoresistance with a particular focus on the involvement of mitochondrial dynamics, mitochondrial $\mathrm{Ca}^{2+}$ signaling, oxidative stress, and metabolism to possibly identify new approaches or targets for overcoming cancer resistance.
\end{abstract}

Keywords: mitochondrial dynamics; mitochondrial $\mathrm{Ca}^{2+}$ homeostasis; metabolic plasticity; drug resistance; cancer

\section{Introduction}

Cancer remains one of the greatest public health issues worldwide. According to the National Cancer Institute (NIH), the incidence between 2013 and 2017 was 442.4 per 100,000 men and women per year, with a death rate of 158.3 per 100,000 men and women per year (https: / / www.cancer.gov / about-cancer/understanding/statistics, accessed on 3 March 2021). The interest in developing novel and successful therapies is ardent and continuous; nevertheless, this pursuit still suffers some failures, such as the rise in chemoresistance and multidrug resistance (MDR).

MDR represents the major cause of treatment failure and cancer relapse after surgical removal. To date, two types of chemoresistance development mechanisms have been reported: intrinsic and acquired [1,2]. Intrinsic chemoresistance, as the name suggests, is an innate characteristic of cancer cells due to preexisting resistance-mediating factors in the tumor mass that impede the effectiveness of the treatment even before it is administered. On the other hand, acquired resistance, which develops after treatment administration, is generally caused by mutations or alterations in the adaptive response machinery that span from the increased expression of therapeutic targets, inactivation of drugs, overexpression 
of transporters for drug extrusion (mdr pumps), promotion of DNA damage repair, and metabolic changes to the activation of alternative survival pathways [3].

An additional feature of this quite intricate scenario is cell heterogeneity in the bulk cancer; indeed, this permits the coexistence of diverse cell populations. Recent findings have outlined that cancer stem cells (CSCs) may be the pioneers of innate/acquired [4-6] conferring and spreading a resistance phenotype in the whole cancer pool and to other organs $[3,4,7,8]$.

Even if CSCs are a small percentage (less than 1-2\%) $[9,10]$ of the cancer population, they have been found in leukemias (such as Acute Myeloid Leukemia [AML]) as in solid tumors (such as breast, lung, brain, prostate, colon, liver and head and neck cancers) [11,12], and generally, their relative abundance is associated with the clinical outcome [13]. As CSCs have stemness features, they are more prone to last in a quiescent state than canonical cancer cells; this is why most of the current treatments that target dividing cells have very little effect on CSCs [14].

As mentioned above, cancer cells with acquired drug resistance may exhibit metabolic changes, whereas CSCs are characterized by great metabolic plasticity that gives them the ability to survive in adverse conditions such as hypoxia [15-17]. Mitochondria play a central role in the bridge between metabolism and tumor progression, as they can decide cell fate [18]. Interestingly, it has been observed that CSCs increase the expression of genes encoding mitochondrial proteins $[19,20]$, highlighting the crucial importance of mitochondria for cancer cell survival, resistance, and spreading.

In recent years, there has been growing interest regarding mitochondria as potential crucial targets for cancer therapy [21], mainly because mitochondria can rapidly adapt to stressful conditions to permit cell survival. In fact, mitochondria are involved in metabolic changes and survival pathways regulating the oxidative stress response, mitochondrial plasticity, known as mitochondrial dynamics (mitochondrial fusion, mitochondrial fission, mitochondrial transfer, mitophagy) and $\mathrm{Ca}^{2+}$ homeostasis [22-27], as they are the site where all these processes are often strictly intertwined.

Therefore, it seems that mitochondrial plasticity is a key feature in many steps of tumorigenesis, especially chemoresistance. Indeed, recent research suggests that in chemoresistant ovarian cancer cells, the mitochondrial bioenergetic switch to oxidative metabolism represents an advantage with respect to their non-resistant counterparts, and this shift occurs along with relevant mitochondrial remodeling [28]. Another recent study showed that the transfer of healthy mitochondria from fibroblasts to HeLa cells or SAS $\mathrm{r}^{0}$ cells (depleted of mitochondrial DNA [mtDNA]) restored their proliferative capacity and sensitivity to cisplatin treatment, suggesting that mitochondrial transfer can be considered a potential therapeutic strategy [29].

With this review, we aimed to gather all the recent findings regarding mitochondrial dynamics and homeostasis to outline their roles in cancer chemoresistance. A deeper understanding of these features could be crucial to overcoming the limitations that chemotherapeutic treatments have in many cancer types to pave the way towards more successful therapies.

\section{Role of Mitochondrial Remodeling (Fusion, Fission, Mitophagy, and Transfer) in Cancer Chemoresistance}

Mitochondrial activities such as fusion, fission, mitophagy, and mitochondrial transfer make mitochondria highly dynamic organelles [30]. The fine-tuned regulation of mitochondrial dynamics allows the maintenance of functional mitochondria through the control of their shape, number, quality, and distribution in cells. In addition, to ensure correct mitochondrial functions, these coordinated dynamic transitions are essential for responding to cellular requirements via rapid morphological adaptation to the metabolic state of the cell [31]. Since many functions of mitochondria involved in cell homeostasis are closely linked to their morphology [32], it is not surprising that dysregulation of mitochondrial dynamics is related to several pathologies ranging from neurodegenerative diseases [33] to ischemic stroke [34] and cancers [35,36]. In particular, impaired mitochondrial dynamics 
have been associated with the initiation and progression of several cancer types and cancer metastasis, CSC survival, and drug resistance [37,38] (Figure 1), thus suggesting that targeting mitochondrial dynamics is a potential therapeutic strategy for fighting cancer. In this section, we critically reviewed the involvement of mitochondrial dynamics in cancer chemoresistance.

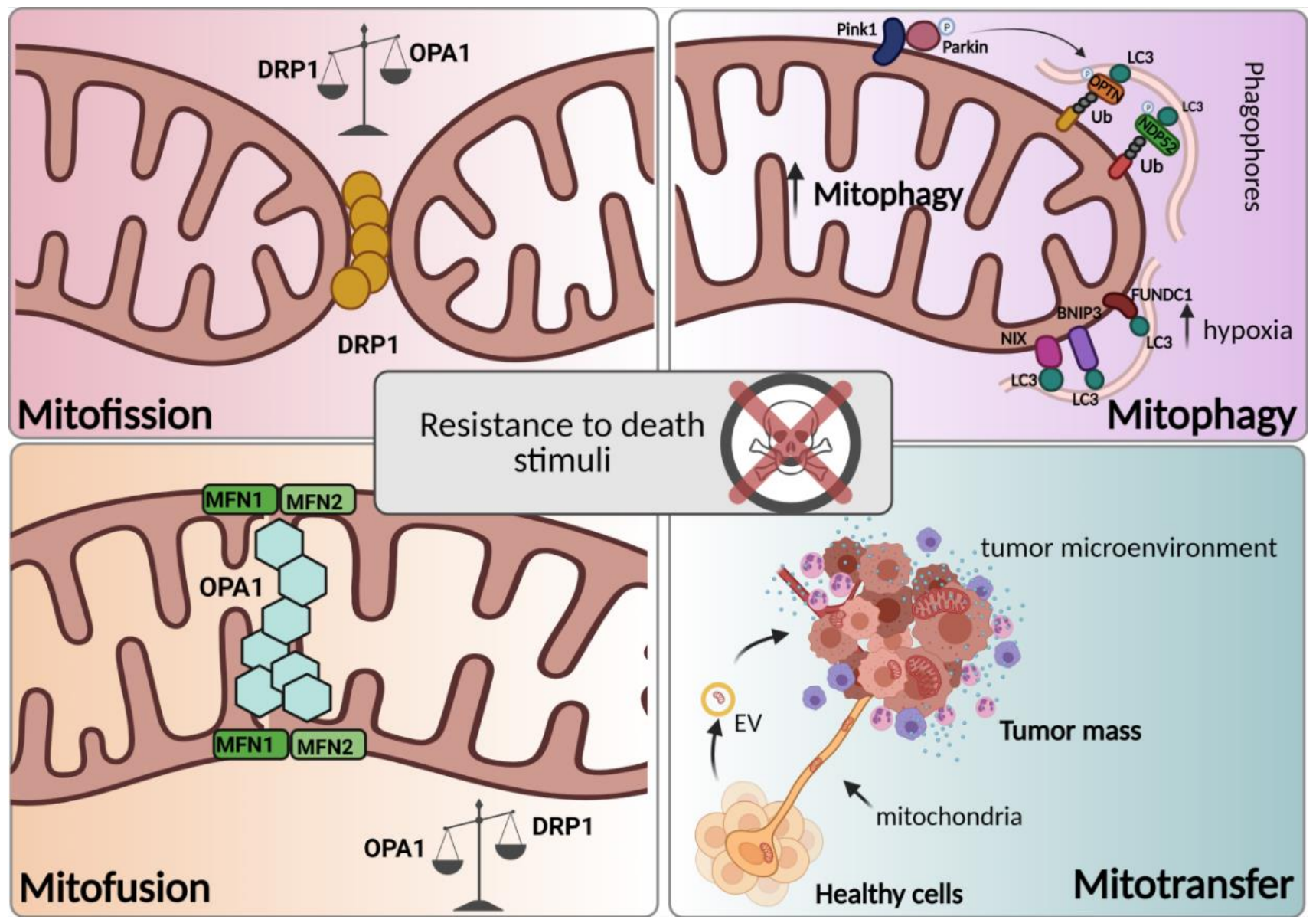

Figure 1. Mitochondrial dynamics in chemoresistance. Mitotransfer, mitophagy, and mitochondrial fusion and fission (respectively, mitofusion and mitofission) are processes related to mitochondrial dynamics. These processes, depending on their activation timing, tumor subtype, and microenvironment, can foster chemoresistance. The details of the processes are reviewed in the paragraph. (Created with Biorender.com, accessed on 18 March 2021).

\subsection{Mitochondrial Fusion and Mitochondrial Fission in Cancer Chemoresistance}

Two opposing processes, mitochondrial fusion and fission, according to the cellular metabolic requirements, allow mitochondria to constantly divide or connect to each other to form networks or fragments, respectively [31,39]. Mitochondrial fusion and fission are important in a variety of cell functions, including the cell cycle [40], developmental processes [41], and apoptosis [42]. Moreover, different functions of mitochondria are reflected in their structure. While fusion is commonly associated with high energy demand, resulting in a hyperfused mitochondrial network with increased ATP production and protection against autophagy [43-47]; fission is mainly linked to apoptosis, facilitating the segregation of mtDNA upon mitosis and eliminating defective mitochondria through selective isolation of parts of the organelle from the network [48-50]. In other words, prosurvival signals are correlated with elongated mitochondria, while cell death is connected to fragmented mitochondria.

However, depending on the cell's state, fusion and fission can be proapoptotic or antiapoptotic, complicating their role in cancer [51,52]. 
Mitochondrial fusion results from the union of two distinct mitochondria into one through a process that requires the coordination of three dynamin-related GTPases, optic atrophy 1 (OPA1) and mitofusin (MFN) 1 and 2 [53,54]. Fusion of the outer mitochondrial membrane $(\mathrm{OMM})$ is mainly carried out by the formation of homotypic and heterotypic oligomers of MFN1 and MFN2, which leads to membrane clustering in a GTP-dependent manner [55,56], whereas OPA1, at IMM, requires MFN1 to mediate mitochondrial fusion $[54,57]$. In contrast to MFN1 and MFN2, OPA1 requires proteolytic cleavages for activation. The OPA1 precursor is imported into the mitochondrion, where it undergoes removal of the $\mathrm{N}$-terminal mitochondrial targeting sequence by peptidases, thus producing the long isoform of OPA1 (1-OPA1) that is embedded in the IMM. Further processing of 1-OPA1 in the matrix is mediated by different proteases to form the OPA1 short isoform (s-OPA1). OMA1 is required for OPA1 cleavage, which occurs at basal levels but is strongly induced by mitochondrial depolarization [58-60], while the intermembrane (i-AAA) protease YME1L is involved in cleavage at the S2 site of OPA1 [61]. The absence of OMA1 in cells results in the inhibition of stress-induced OPA1 processing, affecting both mitochondrial fusion and fission. In this case, l-OPA1 is stabilized, and the formation of s-OPA1 isoforms is prevented, resulting in the maintenance of a tubular mitochondrial network and protection against apoptosis [62]. The combination of long and short Opa1 isoforms is mandatory for fusion, although only the long isoform has been demonstrated to be fusion competent $[60,63]$. Additionally, accelerated OPA1 proteolysis has been reported to trigger mitochondrial fragmentation [64]. A relevant role of mitochondrial fusion in chemoresistance is now emerging; indeed, it has been reported that chemoresistant ovarian cancer cells have more interconnected mitochondrial networks than their chemosensitive counterparts $[65,66]$. Consistently, in the absence of OMA1 or p53, two proteins involved in OPA1 processing, chemoresistant gynecologic cells, show fused mitochondria even in response to cisplatin, reflecting their inability to undergo fragmentation when OPA1 processing is altered [67]. Interestingly, prolonged treatment with venetoclax in AML cells results in drug resistance. In particular, venetoclax-resistant AML cells show upregulation of OPA1, which likely establishes resistance to cytochrome c release upon stimulation [68]. In accordance with the role of mitochondrial fusion in chemoresistance, MFN2 and oxidative phosphorylation (OXPHOS) have been found to be significantly upregulated in surviving leukemia cells since the knockout of MFN2 substantially increases Jurkat sensitivity to doxorubicin [69]. In addition, it has been found that the inhibition of mitochondrial fusion by silencing MFN1 increases cisplatin sensitivity in human neuroblastoma cells [70]. All these findings indicate that mitochondrial fusion strictly relies on the adaptation of metabolic changes by promoting cell survival, increasing ATP production, and decreasing apoptosis and mitochondrial fragmentation, which may provide a potential target for increasing chemotherapy efficacy. However, further investigation unraveling the links between mitochondrial fusion and cell sensitivity to chemotherapy is necessary to develop therapies offering improvement in clinical outcomes.

As stated before, mitochondrial fusion is balanced by opposing fission events. Mitochondrial fission is characterized by the division of one mitochondrion into two mitochondria and primarily requires the action of the master regulator of mitochondrial fission, dynamin-related protein 1 (DRP1), which is a cytosolic guanosine triphosphatase (GTPase) that is recruited to the OMM of mitochondria by outer membrane receptors, including fission protein homolog 1 (FIS1), mitochondrial fission factor (MFF), and mitochondrial dynamics proteins (MIDs) 49/51, [71]. When DRP1 reaches the mitochondrial membrane, it oligomerizes and wraps around the constriction points of dividing mitochondria, promoting mitochondrial fission [72]. Of note, several post-translational modifications regulate the role of DRP1 in mitochondrial fragmentation in response to specific fission stimuli, especially phosphorylation. DRP1 phosphorylation is regulated by a variety of kinases, including PKC $\delta$ [73], Cdk1/cyclin B [49], ERK1/2 [74], $\mathrm{Ca}^{2+} /$ calmodulin-dependent protein kinase I alpha (CaMKIalpha) [75], adenosine monophosphate (AMP)-activated protein kinase (AMPK) [76], and cyclic AMP-dependent protein kinase (PKA) [77]. Al- 
though mitochondrial fission represents the opposite process of mitochondrial fusion, increasing evidence shows an important role of the first process in chemoresistance as well [78]. Interestingly, latent membrane protein 1 (LMP1), a major Epstein-Barr virus (EBV)-encoded oncoprotein, has been found to regulate DRP1 through two oncogenic signaling axes: AMPK and cyclin B1/Cdk1. Thus, in EBV-LMP1-positive nasopharyngeal carcinoma (NPC), mitochondrial fission mediated by DRP1 phosphorylation promotes cell survival and cisplatin resistance. This finding strongly suggests that targeting DRP1 could be a promising therapeutic strategy to overcome resistance in this kind of cancer. Indeed, metformin or cucurbitacin E, which interferes with the DRP1 upstream kinase AMPK or cyclin B1/Cdk1, increased the chemosensitivity of NPC cells to cisplatin [79]. Although several works reported the implication of different fission-independent signaling pathways in chemoprotection following the interactions between leukemia cells and stromal cells [80-82], ERK/DRP1-dependent mitochondrial fission has also been shown to be involved in bone marrow-derived mesenchymal stem cell (MSC)-induced drug resistance in T-cell acute lymphoblastic leukemia cells [83,84].

Hypoxia promotes mitochondrial fission and cisplatin resistance in ovarian cancer cells via ROS; consistently, suppression of mitochondrial fission by Mdivi-1, a putative DRP1 inhibitor, or DRP1 silencing enhanced the cisplatin sensitivity of hypoxic ovarian cancer cells. Therefore, the mitochondrial fission of cancer cells adapting to the hypoxic tumor microenvironment could be a potential target for chemoresistant cells [66,85]. Moreover, although Mdivi-1 is widely reported to inhibit Drp1-dependent fission, recent studies highlighted that the compound acts by reversibly inhibiting complex I as well, thus modifying mitochondrial ROS production, possibly contributing to the observed effects [86]. In addition, it has been reported that Mdivi-1 impaired cell proliferation, also acting on oxidative metabolism [87], highlighting that DRP1-inhibition remains an ongoing challenge. Conversely, it has been reported that increased levels of DRP1 induced by ABT737, an inhibitor of antiapoptotic BCL-2/BCL-XL, promote mitochondrial fission, leading to apoptosis and mitophagy in ovarian cancer cells resistant to cisplatin. Accordingly, Mdivi-1 weakened ABT737-induced processes. Thus, targeting antiapoptotic BCL-2 family proteins may be an emerging therapeutic strategy for patients with cisplatin-resistant ovarian cancer since it allows the induction of DRP1-dependent apoptotic mitochondrial fission [66,88].

Chemoresistance is common in most patients with colorectal cancer. Notably, chemotherapeutic drugs that promote the release of high-mobility group box 1 protein (HMGB1) from dying cells elicit ERK1/2-mediated DRP1 phosphorylation via its receptor for the advanced glycation end product (RAGE). All of these events trigger the autophagy process, inducing chemoresistance and regrowth of the surviving cancer cells after treatment. Administration of an HMGB1 inhibitor or a RAGE blocker abolished DRP1 phosphorylation, enhancing sensitivity to chemotherapeutic treatment by inhibiting autophagy [89]. Another study also elucidated the role of ERK-induced DRP1 phosphorylation in the chemoresistance of bladder cancer cells. The study reported that LASS2 inhibits bladder cancer invasion and chemoresistance through the regulation of ERK-DRP1-induced mitochondrial fission [90].

Since mitochondrial fusion and fission represent adaptive cellular systems to cellular metabolic requirements, multiple mechanisms of the mitochondrial dynamics regulation could represent cancer strategies for developing chemoresistance in a contextdependent manner.

Accordingly, anticancer drugs promoting the release of HMGB1, in colorectal cancers, or increased ROS production and hypoxic conditions in ovarian cancers, are commonly associated with fission-driven chemoresistance. On the contrary, time-dependent exposure to drug in AML, loss of function of p53 in ovarian cancers, increased levels of MFN2 and OXPHOS in response to doxorubicin in Jurkat leukemia cells are usually associated with fusion-driven chemoresistance. Thus, mitochondrial fusion or fission, although opposite processes, depending on the cancer type and on the hypoxic or metabolic state, can be both promoters of cancer chemoresistance. Depending on the conditions, the induction or inhibition of mitochondrial fusion or fission could help in fighting cancer chemotherapy 
resistance. However, more insights into cellular fusion and fission strategies on the basis of chemoresistance have to be further investigated.

\subsection{Mitophagy in Cancer Chemoresistance}

In addition to mitochondrial fusion and fission, proper mitochondrial function is also ensured by an important degradative process involved in mitochondrial quality control and mitophagy. Several studies have shown that mitochondrial fission coordinates with mitophagy, representing a prerequisite to the mitochondrial degradation pathway in many mammalian cell types $[91,92]$. The term mitophagy outlines the selective degradation of damaged mitochondria in a process involving the formation of a double-membrane structure called an autophagosome, which sequesters the organelle, allowing its autophagosomal degradation following fusion with a lysosome [93]. Essentially, the mitophagy pathway can be divided into two types: ubiquitin-mediated mitophagy and receptormediated mitophagy. The most well-studied ubiquitin-mediated pathway involved in cancer chemoresistance is the PINK1-Parkin pathway. Mitochondrial impairment or depolarization leads to the accumulation of phosphatase and tensin homolog (PTEN)-induced kinase 1 (PINK1) at the OMM. Here, the kinase recruits and phosphorylates the E3 ligase Parkin, promoting its E3 ligase activity [94-96]. Once activated, Parkin can ubiquitylate several OMM proteins that are then recognized by ubiquitin-dependent receptors, also known as autophagy receptors, such as p62/SQSTM1 (p62), optineurin (OPTN), NBR1 (neighbor of BRCA1), and NDP52 (nuclear dot protein $52 \mathrm{kDa}$ ). These receptors, which harbor both ubiquitin-binding domains and LC3-interacting regions (LIRs), bind ubiquitinated proteins and promote their degradation by mitophagy through binding to LC3 on the autophagosome membrane [97].

Several mitophagy receptors are involved in PINK-Parkin-independent mitophagy, including Bcl-2/adenovirus E1B 19 kDa interacting protein 3 (BNIP3), BNIP3-like (BNIP3L)/NIX and FUN14 domain-containing protein 1 (FUNDC1), have been found to be associated with chemoresistance. All these receptors are OMM proteins associated with hypoxia-mediated mitophagy that bind LC3 through their own LIR [98-101].

Thus, mitophagy plays a dual role in cancer therapy; on the one hand, mitophagy can induce cancer cell death; on the other hand, it is able to promote cancer cell survival [102], indicating the complexity of mitophagy regulation in cancer. The role of autophagy/mitophagy differs in different stages of tumor development [103]. Although the cancer type and tumor microenvironment complicate the role of this degradative pathway in tumorigenesis, it is well accepted that in the early stage of cancer progression, mitophagy inhibits tumor progression, while in the latest stages of tumor development, the occurrence of mitophagy promotes cancer cell survival [102]. Importantly, the occurrence of drug resistance to common chemotherapeutic drugs, including cisplatin, doxorubicin (Dox), 5-fluorouracil (5-FU), and paclitaxel, due to autophagy or mitophagy often leads to treatment failure [104]. Therefore, an increasing number of studies highlight the involvement of the mitophagy process in chemoresistance.

High levels of PINK1 expression have been associated with a poorer prognosis in several tumor types. In non-small-cell lung cancer (NSCLC), PINK1 downregulation potentiates cisplatin-induced NSCLC cell apoptosis [105,106], and similar results have been obtained in esophageal squamous cell carcinoma (ESCC) patients undergoing neoadjuvant chemotherapy [107]. In support of the role of mitophagy in cancer chemoresistance, it has been reported that the inhibition of PINK1/Parkin-dependent mitophagy through PINK1 siRNA, mdivi-1, or bafilomycin A1 (Baf A1) promotes B5G1-induced cell death, sensitizing multidrug-resistant cancer cells to a new betulinic acid analog, B5G1 [108]. Notably, depletion of FUNDC1 in patients with cervical cancer, where high levels of FUNDC1 are associated with a poor prognostic outcome, significantly enhances cell sensitivity to cisplatin and ionizing radiation [109]. Further, in hepatocellular carcinoma (HCC), it has been reported that treatment with palliative transarterial embolization/transarterial chemoembolization (TAE/TACE) promotes survival and the acquisition of a more invasive 
phenotype in HCC cells [110]. The blockage of DRP1-mediated mitochondrial fission, and thus mitophagy, increases the incidence of mitochondrial apoptosis in HCC cells, suggesting a new possible approach of targeting mitophagy to enhance apoptosis in TAE/TACE-mediated ischemic hypoxic conditions [111].

In addition to the specific activation of mitophagy, cancer cell heterogeneity adds a further layer of complexity to this process with respect to cancer chemoresistance. Indeed, CSCs are known to be drug-resistant. Doxorubicin-induced mitophagy contributes to drug resistance, and BNIP3L silencing enhances the sensitivity to doxorubicin in human colorectal CSCs isolated from HCT8 cells, suggesting that mitophagy contributes to drug resistance [112]. All these findings indicate a crucial role of mitophagy in cancer chemoresistance. Thus, combining drugs targeting mitophagy with chemotherapy drugs represents an encouraging way to overcome chemoresistance and improve therapeutic outcomes in several cancer types.

\subsection{Mitochondrial Transfer in Cancer Chemoresistance}

Mitochondrial dynamics are accompanied by intercellular dynamics in a mechanism called mitochondrial transfer. In both physiological and pathological conditions, two cells respond to external signals, including chemokines and cytokines, as well as therapeutic drugs, directly transmitting biological information via horizontal transfer [113-115]. The physical processes of this cellular communication mechanism include the establishment of gap junctions, tunneling nanotubes (TNTs), and extracellular vesicle (EV) transport [116-119]. Among these connection mechanisms, a functional role for TNTs and EVs in several cancer types is emerging. TNTs are transient cytoplasmic extensions characterized by long actin-based fibers, with lengths of several hundred micrometers and diameters ranging from 50 to $1500 \mathrm{~nm}$, that connect nonadjacent cells [116,120]. TNTs allow the trafficking of relatively large cargos, including organelles such as mitochondria, through motor-adaptor protein complexes related to the mitochondrial Rho GTPase Miro1, from a donor cell to a recipient cell [121]. EV communication is characterized by the exchange of signals, including soluble and insoluble factors, as well as structural proteins, nucleic acids, and lipids, through the release of membrane-enclosed particles termed EVs [122-124]. EVs include several kinds of vesicles, including exosomes (30-100 nm in diameter), microvesicles (MVs) (100-1000 $\mathrm{nm}$ in diameter), and a very recently identified cancer-derived EV population called oncosomes (1-10 $\mu \mathrm{m}$ in diameter) [125]. In recent decades, increasing attention has been given to intercellular communication, identifying this mechanism as a crucial factor inducing heterogeneity in the tumor microenvironment, highlighting its role in contributing to chemoresistance [113]. TNT-mediated mitochondrial transfer, first observed in mesothelioma [126,127], occurs both between cancer cells and between cancer and normal cells of the microenvironment of several cancer types [128-130]. An additional role of TNT in promoting drug resistance is through intercellular drug efflux, as demonstrated in chemotherapy-induced pancreatic cancer cells [113]. Functional benefits from the acquisition of mitochondria have been documented; the common result of mitochondrial transfer in recipient cells is the acquisition of a survival advantage from the mitochondrial uptake process. Indeed, mitochondria transferred by TNTs increase the OXPHOS output and ATP production of the target cells, affecting their metabolism, and as functional consequences, recipient cancer cells exhibit enhanced proliferative, migratory properties and resistance to stress [131-133]. Therefore, it is not surprising that a number of studies have reported that cancer cells take advantage of this mechanism to enhance their chemoresistance and increase their regrowth potential after treatment. Consistently, it has been reported that mitochondrial transfer from endothelial cells to MCF7 breast cancer cells promotes their resistance to doxorubicin [134]. Moreover, functional mitochondria derived from bone marrow stromal cells have been found to increase resistance to cytarabine treatment in AML [135]. Accordingly, it has been proposed that mitochondrial transfer, from primary bone marrow stromal cells (BMSC) to the primary AML blasts, via TNT likely contributes to chemoresistance in AML [136]. In a study on ovarian cancer and breast cancer 
cell lines, it was demonstrated that the preferential transfer through TNT of mitochondria was from endothelial to cancer cells, demonstrating that mitochondria uptake, inducing phenotypic advantage in recipient cells, resulted in the acquisition of chemoresistance [128]. TNT mitochondrial transfer has also been linked to human tumor-activated stromal cells (TASCs) and glioblastoma cells, conferring resistance to standard treatments (radiotherapy and chemotherapy) [137]. Drug resistance in T-ALL makes this leukemia one of the most aggressive hematologic malignancies. Interestingly, it has been demonstrated that upon the induction of oxidative stress by chemotherapeutic drugs, T-ALL cells were able to transfer mitochondria to MSCs; this process is mediated by TNTs and ICAM- 1 and contributes to the cell adhesion-mediated drug resistance [138].

In addition, it has been demonstrated that MSCs transfer mitochondria to damaged neural stem cells (NSCs) via the formation of TNTs, allowing NSC survival after cisplatin treatment. Consistently, the inhibition of actin polymerization in MSCs blocks the transfer of mitochondria and abrogates the beneficial effect of MSCs on NSCs. Conversely, the enhancement of mitochondrial transfer by Miro1 overexpression further increases the survival of NSCs after cisplatin treatment [139]. In line with these studies, the horizontal transfer of mtDNA in circulating EVs from patients with hormonal therapy-resistant metastatic breast cancer promotes the exit of therapy-induced cancer stem-like cells from dormancy, leading to endocrine therapy resistance in OXPHOS-dependent breast cancer [140]. Since mitochondrial transfer clearly provides survival advantages following chemotherapy, this mechanism could represent a future therapeutic target for several chemoresistant cancer types.

\section{Role of Proteins That Regulate Mitochondrial $\mathrm{Ca}^{2+}$ Homeostasis in Cancer ChemoResistance and Death Resistance: An Overview}

$\mathrm{Ca}^{2+}$ signaling is essential for a plethora of cell functions; therefore, $\left[\mathrm{Ca}^{2+}\right]_{\mathrm{i}}$ must be kept under control to enable proper cell physiology. Specifically, extracellular $\left[\mathrm{Ca}^{2+}\right]$ is greater than $1 \mathrm{mM}$, while cytosol has a $\left[\mathrm{Ca}^{2+}\right]$ concentration of approximately $100 \mathrm{nM}$, and intracellular stores in the sarco/endoplasmic reticulum have a concentration $>100 \mu \mathrm{M}$; this homeostasis is finely tuned and maintained by $\mathrm{Ca}^{2+}$ transport systems, ion channels, $\mathrm{Ca}^{2+}$ pumps, $\mathrm{Ca}^{2+}$ sensor proteins and other $\mathrm{Ca}^{2+}$-binding proteins that are located at the plasma membrane, endoplasmic reticulum (ER), mitochondria, or cytoplasm [141,142]. Mitochondria are crucial organelles involved in the regulation of cell $\mathrm{Ca}^{2+}$ homeostasis. $\mathrm{Ca}^{2+}$ regulates the mitochondrial respiration rate, which depends on ATP production; nevertheless, too much $\mathrm{Ca}^{2+}$ could also prompt mitochondrion-mediated apoptosis [143]. Cancer cell survival strictly depends on the combination of sustained mitochondrial bioenergetics together with evasion from death stimuli; to counterbalance metabolic demand and survival signals, cells have evolved mitochondrial $\mathrm{Ca}^{2+}$ influx and efflux systems, which have been found to be extremely helpful for tumorigenesis [144]. Due to its multifaceted role in regulating the fate between cell survival and death, mitochondrial $\mathrm{Ca}^{2+}$ signaling pathways are under growing investigation since the proteins involved in those pathways may represent alternative targets for cancer therapy.

Together with mitochondria, the ER plays a central role in the regulation of $\left[\mathrm{Ca}^{2+}\right]_{\mathrm{i}}$, specifically via a series of proteins and factors constituting membranous tethering systems named mitochondria-associated membranes (MAMs) [145-154].

In fact, mitochondria-ER crosstalk has a pivotal role in cell adaptation to stress stimuli. MAMs may play a role in response to chemotherapeutic treatment by regulating $\mathrm{Ca}^{2+}$ signaling, as the ER can regulate $\mathrm{Ca}^{2+}$ transfer not only to the mitochondria but also to the cytoplasm. Chemotherapeutic drugs cause a rapid increase in $\left[\mathrm{Ca}^{2+}\right]_{\text {cyt }}[155,156]$; moreover, these shifts in cytosolic $\mathrm{Ca}^{2+}$ are thought to be early markers of cytotoxicity in response to various oxidative stress stimuli $[155,156]$.

However, mitochondrial $\mathrm{Ca}^{2+}$ homeostasis may also be affected by some chemotherapeutic drugs since these drugs can either have a direct effect on mitochondria or indirectly act on $\mathrm{Ca}^{2+}$ uptake by affecting mitochondrial membrane potential $(\Delta \Psi)$ [157]. 
Furthermore, it has been shown that patient-derived mesothelioma cancer cells critically deregulate intracellular $\mathrm{Ca}^{2+}$ signaling, mainly due to alterations in mitochondrial $\mathrm{Ca}^{2+}$ uptake. This feature is correlated with evident resistance to cell death upon chemotherapeutic treatment; indeed, the restoration of proper $\mathrm{Ca}^{2+}$ homeostasis resulted in increased sensitivity to the drugs [158].

The relationship between mitochondrial $\mathrm{Ca}^{2+}$ uptake and cell death induction is not unambiguous, since $\mathrm{Ca}^{2+}$ uptake is necessary for the maintenance of $\Delta \Psi$ as ATP is produced; however, a persistent $\mathrm{Ca}^{2+}$ signal towards mitochondria is perceived as a stress stimulus, thus translating into apoptosis activation (for a review on the mitochondrial $\mathrm{Ca}^{2+}$ issue, see [155]).

To date, the relevance of intracellular $\mathrm{Ca}^{2+}$ signaling in tumorigenesis and chemoresistance has undeniably been acknowledged; however, the majority of evidence takes into consideration proteins located either on the ER membrane (STIM, SERCA, IP3R2, and IP3R3) or plasma membrane (PMCAs, ORAI, TRPCs, TRPMs, TRPVs, and CACNAs) or soluble proteins (calpains, S100 family, and calmodulin), which have effects on $\mathrm{Ca}^{2+}$ homeostasis overall [159-166].

The purpose of this chapter is to provide new insights into the role of some of the most critical mitochondrion-resident or -associated proteins involved in the regulation of tumor drug resistance through $\mathrm{Ca}^{2+}$ signaling, pointing towards potential novel investigation targets (Figure 2).

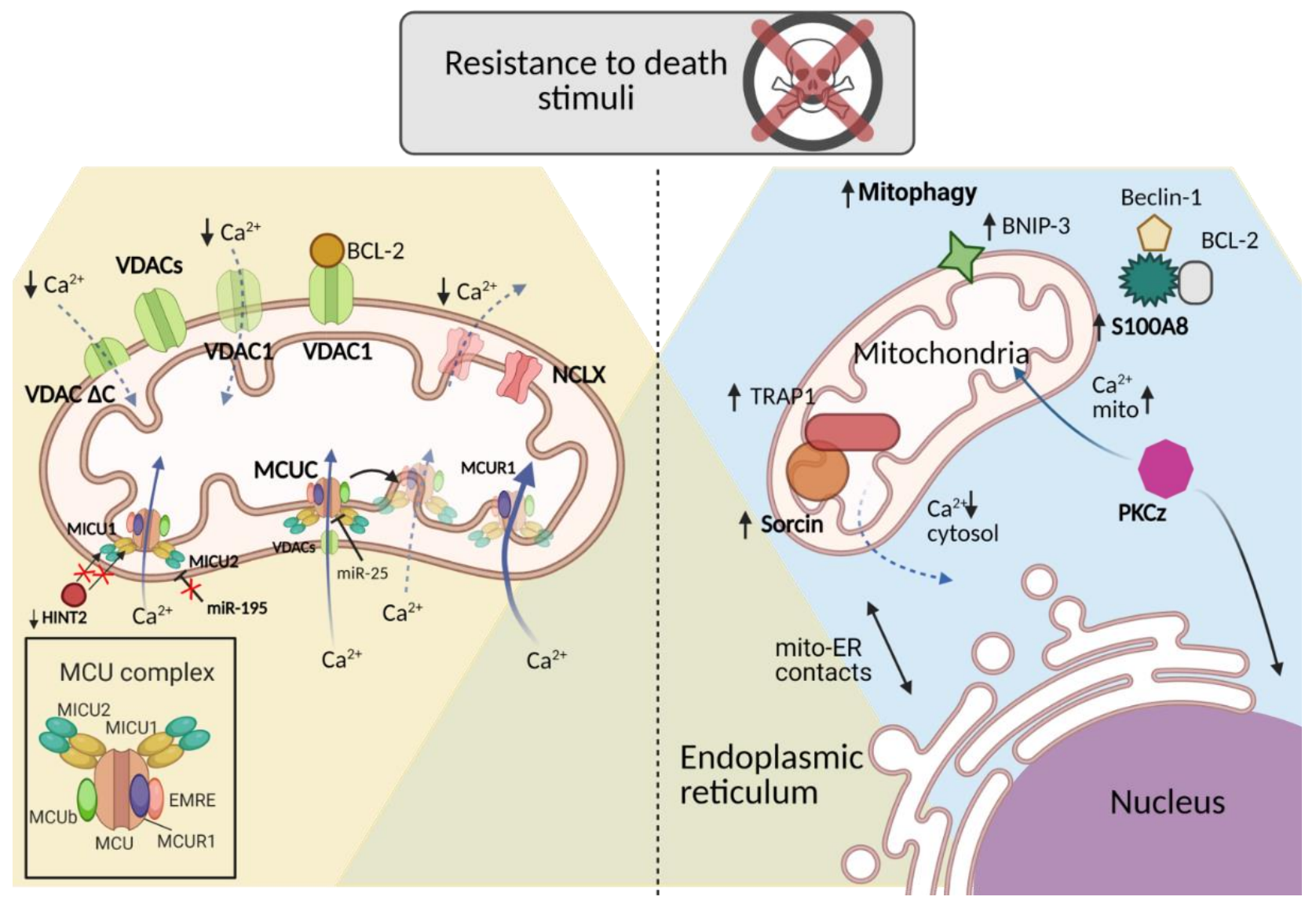

Figure 2. Mitochondrial $\mathrm{Ca}^{2+}$ related proteins in chemoresistance regulation. Mitochondrial-resident proteins and cytosolic mitochondrial-related proteins are able to regulate mitochondrial $\mathrm{Ca}^{2+}$ homeostasis affecting the sensitivity towards chemotherapeutic treatments. The mechanisms of regulation of mitochondrial $\mathrm{Ca}^{2+}$ homeostasis in relation to different cancer types and treatments are detailed in the paragraph. (Created with Biorender.com, accessed on 18 March 2021). 


\subsection{Mitochondrial Membrane Proteins}

The contribution of mitochondria to the chemoresistant phenotype may be summarized in two ways: (i) mitochondrial ATP production is necessary for the activity of mdr pumps (mdr1 and mdr4), also known as P-glycoproteins (P-gp), that are ATP-binding cassette family members involved in the active extrusion of xenobiotics outside the cells (see introduction); (ii) defective mitochondrial outer membrane permeabilization (MOMP) or impaired activation/opening of the mitochondrial permeability transition pore (mPTP), that is involved in the release of proapoptotic factors, such as cytochrome c [167].

For these reasons, the ion channels residing both in the OMM and IMM may impact resistance to death stimuli, since OMM channels participate in the permeabilization process, while the IMM channels regulate the maintenance and adaptation of $\Delta \Psi$, thus influencing the efficiency of mitochondrial respiration and ROS production [168,169].

Next, we critically review the most important proteins in both the OMM and IMM, outlining their implications in resistance to death stimuli in cancer cells.

\subsubsection{The Mitochondrial $\mathrm{Ca}^{2+}$ Uniporter (MCU) Complex}

The MCU complex (MCUC) is a macromolecular complex consisting of regulatory and pore-forming subunits [170]; the pore consists of oligomers of MCU located in the IMM formed by two transmembrane domains, where the $\mathrm{C}$ - and $\mathrm{N}$-termini point to the mitochondrial matrix [171]. Among the regulatory subunits, mitochondrial calcium uptake protein 1 (MICU1) exerts a gatekeeper function, stabilizing the closed state of the MCUC, thus allowing $\mathrm{Ca}^{2+}$ accumulation in the mitochondrial matrix but inhibiting mitochondrial $\mathrm{Ca}^{2+}$ entry [172]. MICU2, which has a 25\% identity with MICU1, interacts with both MICU1 and MCU, and its function is still debated [173]. EMRE, an efflux multidrug resistance protein, is a single-pass membrane member of the complex that functions as a bridge between MICU1 and MCU, and its loss causes the same reduction in mitochondrial $\mathrm{Ca}^{2+}$ uptake as MCU depletion [174]. MCUb is an MCU isogene that acts as an endogenous dominant-negative isoform [175]. Finally, mitochondrial calcium uniport regulator 1 (MCUR1) enhances MCU activity by directly interacting with MCU but not with MICU1 [176].

Mitochondrial $\mathrm{Ca}^{2+}$ overload due to MCU activation causes MPTP opening and the release of factors that initiate necrosis and/or apoptosis [151,177]. When cancer cells are treated with proapoptotic stimuli, the expression of MCU relates to the sensitivity to these treatments [178]. Moreover, it seems that a chronic increase in mitochondrial $\mathrm{Ca}^{2+}$ load through MCU leads to mitochondrial stress and fragmentation of the mitochondrial network [167].

Regarding the implication of MCU in chemoresistance, there is evidence that in human colon cancer, microRNA-25 (miR-25) is able to target and downregulate MCU expression, decreasing mitochondrial $\mathrm{Ca}^{2+}$ uptake and favoring cancer cell proliferation and resistance towards proapoptotic stimuli since the reintroduction of MCU sensitizes cancer cells to the treatment $[179,180]$. On the other hand, a recent study demonstrated that the overexpression of receptor-interacting protein kinase 1 (RIPK1) and its consequent interaction with $\mathrm{MCU}$ is able to increase mitochondrial $\mathrm{Ca}^{2+}$ uptake, resulting in an increase in the proliferation of cancer cells [181].

Additionally, other evidence shows that in HCC, the expression of MCUR1 is increased and is correlated with an increase in MCU activity leading to greater mitochondrial $\mathrm{Ca}^{2+}$ uptake, which enables desensitization to proapoptotic stimuli [182].

In breast cancer patients, it has been demonstrated that survival rate is negatively correlated with an increase in MCU expression and a decrease in MICU1 expression, suggesting that MICU1 might act as an oncosuppressor [183]. Other evidence shows that the downregulation of MICU1 and MICU2, which occurs in pancreatic cancer cells, is facilitated by histidine triad nucleotide-binding protein (HINT2), whose decreased expression correlates with a poor prognosis and chemoresistance [184]. Furthermore, MICU1 knockout cells lose MCU gatekeeper function and become more susceptible to 
apoptotic and stress stimuli since oxidative stress and ROS production increase during mitochondrial $\mathrm{Ca}^{2+}$ uptake [185].

Enhanced MICU1 expression has been found in many types of cancers, and it is related to poor clinical outcomes and increased glycolysis and chemoresistance. Recent evidence shows that miR-195 targets the MICU1 $3^{\prime}$-untranslated region (UTR), lowering its expression; in fact, stable miR-195 expression in ovarian cancer human xenograft models significantly reduces tumor growth and enhances cell survival. Thus, miR-195, which regulates MICU1, can be exploited to normalize abnormal MICU1 expression and reverse chemoresistance [186].

Altogether, both MCU and its negative regulator MICU1 may be considered important potential targets for combating cancer chemoresistance [187-189].

\subsubsection{Voltage-Dependent Anion Channels (VDACs)}

Mitochondrial porins are also known as VDACs, and they reside in the OMM and take part in MOMP upon apoptotic stimulation. The porin family includes three isoforms named VDAC1, VDAC2, and VDAC3 [190]; the first two isoforms are the most involved in MOMP [191-194]. VDAC1 mediates the flow of small molecules, such as ROS, ATP, $\mathrm{Ca}^{2+}$ ions, and water molecules, across the OMM, making it crucial for metabolic signaling and $\mathrm{Ca}^{2+}$ signaling under physiological conditions [167]. This isoform is expressed in many types of cancers [192] and plays an essential role in tunneling ATP across the OMM directly to the first enzyme of glycolysis, hexokinase, whose expression is increased in cancer cells helping to maintain the Warburg effect [195-197].

The importance of VDAC1 has also been reported in chemoresistant cancer patients since a truncated but channel-forming isoform of VDAC1 (VDAC1- $\Delta C$ ) has been detected in late-stage tumor tissue and tissues from chemoresistant lung adenocarcinoma patients; these findings demonstrate that VDAC1- $\Delta \mathrm{C}$ is induced by HIF-1 in hypoxic conditions, conferring protection from apoptosis [198-200].

Another study highlighted that dexamethasone-resistant childhood acute lymphoblastic leukemia (ALL) patients showed lower expression levels of VDAC1 than healthy controls; hence, VDAC1 might be considered a predictor of the chemotherapy response for childhood ALL [201].

Regarding VDAC2, high transcript levels were found to be associated with a greater risk of tumor recurrence and resistance to hormonal therapy in high-risk breast cancer patients [202].

Furthermore, VDAC1 anchors to antiapoptotic BCL-2 and BCL-XL proteins, where BCL-2 is able to decrease VDAC1 channel conductance by possibly binding directly to it. Indeed, synthetic peptides corresponding to the VDAC1/BCL-2-interacting region decrease protection against staurosporine-induced apoptotic cell death in BCL-2-overexpressing cells, suggesting that a VDAC1-based peptide may prevent BCL-2 binding to the OMM, thus potentiating the efficacy of chemotherapy [203]. Intriguingly, the efficacy of VDAC1based peptides has been proven over the years in different cancers by preclinical models [204]. It has been reported that these peptides can prevent the interaction with hexokinase II, BCL-XL, and BCL-2 in in vivo models [205,206].

Then, the great challenge to overcoming VDAC-mediated chemoresistance would be the design of specific VDAC1 inhibitors since it has been reported that VDACs are "druggable" channels $[187,207]$ and isoform-specific inhibitors are so far unavailable.

\subsection{3. $\mathrm{Na}^{+} / \mathrm{Ca}^{2+} / \mathrm{Li}^{+}$Exchanger (NCLX)}

The majority of mitochondrial $\mathrm{Ca}^{2+}$ extrusion is mediated by NCLX, and the proper balance between $\mathrm{Ca}^{2+}$ uptake by MCU and $\mathrm{Ca}^{2+}$ extrusion by NCLX has a critical role in the maintenance of mitochondrial $\mathrm{Ca}^{2+}$ homeostasis, cell metabolism, and cell fate in general [208]. Although mitochondrial $\mathrm{Ca}^{2+}$ homeostasis alteration can be considered a cancer hallmark, the details of its role in the regulation of cancer progression, metastasis and chemoresistance are still poorly understood. 
In the previous section, we discussed the role of MCU in cancer progression and chemoresistance and how the altered expression of its components or of MCU itself increases $\mathrm{mtCa}^{2+}$ intake with diverse outcomes in terms of cancer cell progression. The NCLX-mediated process, however, occurs approximately 100-fold slower than that of MCU; thus, NCLX function is a rate-limiting factor in the regulation of mitochondrial $\mathrm{Ca}^{2+}$ homeostasis [208,209].

Although NCLX plays an essential role, its role in cancer biology has not yet been fully investigated.

A recent work by Pathak and collaborators demonstrated that NCLX loss decreases mitochondrial $\mathrm{Ca}^{2+}$ extrusion and, as a consequence, inhibits proliferation and primary tumor growth while enhancing metastasis and chemoresistance in colorectal cancer. This dichotomous and apparently contradictory role of NCLX is supported by evidence that a decrease in its expression is accompanied by the upregulation of genes involved in epithelial-mesenchymal transition (EMT), cancer stemness, and downregulation of cell cycle progression mediator genes. These changes result in mitochondrial $\mathrm{Ca}^{2+}$ overload, membrane depolarization, and increased mitochondrial ROS production, which enhances the mesenchymal phenotype, driving colorectal cancer towards metastatic dissemination and treatment resistance [210].

\subsection{Soluble Mitochondria-Related Proteins}

Other than the role exerted by the proteins located at the IMM or the OMM, it is known that there are soluble cytoplasmic proteins able to modulate mitochondrial plasticity and $\mathrm{Ca}^{2+}$ homeostasis in many pathophysiological settings. In recent years, researchers have focused on proteins that can locate, under certain conditions, at MAMs to regulate the function of channels or receptors resident in the ER or mitochondrial membranes. Nevertheless, these proteins that are normally soluble in the cytoplasm are able to migrate to these membranes, regulating intracellular $\mathrm{Ca}^{2+}$ homeostasis in many pathological conditions, such as cancer, inflammation, diabetes, and neurodegeneration $[24,25,211]$.

In the next section, we will focus on the role of some of the soluble proteins, other than the ones that migrate to MAMs, whose involvement in the regulation of mitochondrial $\mathrm{Ca}^{2+}$ homeostasis has been linked to the chemoresistant phenotype in cancer cells or patients. The current findings suggest that not only mitochondria isolated from cells but also mitochondria-associated soluble proteins may have dynamic action that might be crucial in the understanding of the drug resistance condition.

\subsubsection{S100A8}

S100A8 is a part of the 22-member calcium-binding EF hand-containing superfamily, and it is a multifunctional protein able to heterodimerize with S100A9 to form calprotectin involved in the sequestration of divalent cations, acting mainly in the regulation of the innate immune system [212,213].

According to the literature, S100A8 is involved in inflammation, cell proliferation, and oncogenesis [214]; indeed, S100A8 has been reported to be associated with apoptosis, autophagy, myeloid differentiation, and chemotherapy resistance [215-217]. Moreover, S100A8 is widely expressed in many tissues and cells, but it is particularly abundant in myeloid cells [218].

Some studies have reported that S100A8 has a role in mitophagy promotion in cancer cells related to the crosstalk between mitochondria and lysosomes mediated by ROS or via the activation of the autophagy initiation complex BECN1-PI3KC3 (see mitophagy section in this review for further details) [215,217].

Furthermore, autophagy and mitophagy have been ascertained to play an essential role in chemotherapy resistance [219]. Indeed, the inhibition of autophagy may promote sensitivity to chemotherapeutic treatment and apoptosis in many types of malignant cancers [220]. Moreover, multiple chemotherapeutic drugs are able to increase the 
autophagic/mitophagic flux by promoting the drug resistance phenotype and cell survival [221,222].

In a recent work by Zhang and coworkers, the relationship between S100A8, mitophagy, and chemotherapy resistance in B-cell lymphoma cells were characterized. They reported that S100A8 increased drug resistance through the stimulation of BECN1-PI3KC3 and BECN1-BCL-2 complex formation, prompting early mitophagic signaling. In addition, S100A8 enhanced BNIP3 expression, boosting mitophagic signaling activation [223]. BNIP3 is a $19 \mathrm{kDa} \mathrm{BH} 3$-only protein located at the mitochondria-ER interface; specifically, it is anchored to the OMM through the $\mathrm{C}$-terminal domain, while its $\mathrm{N}$-terminal domain points to the cytoplasm. BNIP3 is an autophagy and mitophagy inducer (see the paragraph) and triggers cell death by affecting mitochondrial function [217,224-226]. It has been reported that its aberrant expression is related to mitochondrial $\mathrm{Ca}^{2+}$ homeostasis and promotes cell death $[100,227]$.

Thus, S100A8, a small $\mathrm{Ca}^{2+}$-binding protein, might represent an intriguing link between chemoresistance, mitochondrial $\mathrm{Ca}^{2+}$ homeostasis, and mitophagy.

\subsubsection{Sorcin}

Soluble resistance-related calcium-binding protein (Sorcin) is a $22 \mathrm{kDa}$ soluble protein belonging to the Penta EF-hand (PEF) protein family. Basically, Sorcin works as a $\mathrm{Ca}^{2+}$ sensor in the cytoplasm, as its role was firstly characterized in cardiomyocytes. Indeed, it takes part in the relaxation process after excitation-contraction coupling (EC coupling), by restoring $\left[\mathrm{Ca}^{2+}\right]_{\mathrm{i}}$ to resting conditions $[228,229]$ and by activating SERCA pumps at the ER, voltage-dependent L-type $\mathrm{Ca}^{2+}$ channels, and $\mathrm{Na}^{+} / \mathrm{Ca}^{2+}$ exchangers (NCXs) at the plasma membrane, and possibly MCU at mitochondria while inhibiting the ryanodinic receptor (RyR) at the ER [230-234].

In addition to its role in the regulation of intracellular $\mathrm{Ca}^{2+}$ homeostasis, as the name itself suggests, it has been found to be widely overexpressed in many cancer types, especially in chemotherapy-resistant specimens [235-239]. In many cases, the chemoresistant phenotype was a result of Sorcin co-amplification with $m d r 1$, a gene coding for an ATPbinding cassette pump considered a biomarker of MDR since its overexpression facilitates the extrusion of drugs from cells [240-245]. Moreover, it has been demonstrated that Sorcin overexpression is related to a poor clinical outcome in leukemia patients [246,247], and the combination of Sorcin silencing or depletion and chemotherapy treatment improves the effectiveness of treatment and the sensitivity to death stimuli [248-254].

In addition, it has been reported that a shorter isoform of Sorcin $(18 \mathrm{kDa})$ interacts with TRAP1, a mitochondrial chaperone (Hsp75) with antioxidant and antiapoptotic functions, in mitochondria. TRAP1 exerts a role in MDR in cancer cells and is upregulated together with Sorcin in colorectal carcinoma cells; moreover, their interaction is required for Sorcin localization at mitochondria and TRAP1 stability [255]. TRAP1 and Sorcin are co-upregulated in cancer, and this feature is considered a marker of drug resistance, but their reciprocal regulation also relates to TRAP1 translational control of Sorcin; indeed, TRAP1 silencing relates to Sorcin protein instability and degradation [255]. Moreover, this quality control exerted by TRAP1 on Sorcin protects against apoptosis either induced by ER stress pathway activation or paclitaxel administration in breast carcinoma [256].

A recent publication also showed that Sorcin silencing increases mitochondria-ER proximity, while overexpression decreases the proximity with an effect mainly mediated by cytosolic $\left[\mathrm{Ca}^{2+}\right]$ alteration [257]. This evidence indicates that the Sorcin-mitochondria relationship is a crucial feature in the regulation of cancer cell survival and chemotherapy resistance, suggesting a potential role of proto-oncogenes as well as an intriguing therapeutic target since Sorcin links $\mathrm{Ca}^{2+}$ homeostasis to the mitochondrial response to stress stimuli, which is related to drug resistance. 


\subsubsection{PKCᄃ}

Protein kinase C (PKC) is part of a protein family that comprises serine/threonine kinases that are involved in a large number of signaling pathways from cell proliferation to apoptosis and from muscle contraction to secretion [258-260]. The members of this protein family have been subdivided into three classes: (i) conventional PKCs (isoforms $\alpha, \beta 1$, $\beta 2$, and $\gamma$ ) activated by diacylglycerol and $\mathrm{Ca}^{2+}$, (ii) novel PKCs $(\delta, \varepsilon, \eta$, and $\theta$ ) activated by diacylglycerol and $\mathrm{Ca}^{2+}$-independent, and (iii) atypical PKCs $(\lambda$ and $\zeta$ ) that are both diacylglycerol- and $\mathrm{Ca}^{2+}$-independent [261]. Interestingly, $\mathrm{Ca}^{2+}$ activation of some PKCs and PKC kinases affects the spatiotemporal pattern of the $\mathrm{Ca}^{2+}$ cellular response since it has been noted that PKCs can modulate agonist-mediated $\mathrm{Ca}^{2+}$ release from the ER and differentially decode low- and high-frequency $\mathrm{Ca}^{2+}$ spikes [262,263].

Among the isoforms, $\mathrm{PKC} \zeta$ is implicated in either apoptotic or mitogenic signals as it acts on different pathways. These characteristics provide important implications for PKC $\zeta$ in tumorigenesis [264-268]. Moreover, it has been reported that PKC $\zeta$ acts as an antiapoptotic factor reducing cancer cell sensitivity to chemotherapeutic treatment $[269,270]$ and is possibly implicated in linking cancer-related inflammation and chemoresistance via NF-kB activation and nuclear translocation [271]. Indeed, there is evidence that upon oxidative stress, $\mathrm{PKC} \zeta$ is able to translocate to the nucleus and to increase resistance to apoptotic inducers; in turn, a recombinant nuclear $\mathrm{PKC} \zeta$ inhibitor restores the sensitivity towards apoptotic stimuli in chemoresistant cells [272].

It has also been demonstrated that PKC $\zeta$, similar to some other PKCs, is linked to the regulation of mitochondrial $\mathrm{Ca}^{2+}$ concentration upon agonist stimulation. Specifically, this isoform increases mitochondrial uptake of $\mathrm{Ca}^{2+}$ upon histamine stimulation with no significant variation in the increase in ROS production or $\Delta \Psi$, which can be considered the $\mathrm{Ca}^{2+}$ driving force in the mitochondria; no significant changes in either cytosolic or ER $\mathrm{Ca}^{2+}$ concentration occur during this process [273].

Although it is mainly soluble and expressed in the nucleus, $\mathrm{PKC} \zeta$ affects mitochondrial $\left[\mathrm{Ca}^{2+}\right]$ with possible implications in cancer progression regulation and multidrug resistance in a way that has not yet been fully disclosed. Thus, the understanding of the signaling pathways in which $P K C \zeta$ lies at the crossroads between mitochondrial $\mathrm{Ca}^{2+}$ regulation and chemoresistance would be extremely helpful and interesting in the development of novel therapeutic strategies.

\section{Oxidative Stress and Bioenergetic Remodeling in Chemoresistance}

In 1954, Gerschman and his group first theorized about the toxic effects of oxygen due to partially reduced forms known as free radicals [274], generated as a byproduct of metabolic processes. ROS include the superoxide anion $\left(\mathrm{O}_{2}^{-}\right)$, singlet oxygen $\left({ }^{1} \mathrm{O}_{2}\right)$, hydrogen peroxide $\left(\mathrm{H}_{2} \mathrm{O}_{2}\right)$, and hydroxyl radical (HO-). Free radicals also include reactive nitrogen species (RNS). These unstable and partially reduced oxygen derivatives act as second messengers in cell signaling. Within the cell, they play a double role since they have both beneficial and deleterious effects. On the one hand, at low doses, they are involved in intracellular signaling and adaptive and innate immune responses. On the other hand, high levels lead to biological damage known as oxidative stress as a result of an imbalance between ROS production and antioxidant defense systems [275,276]. Mitochondria represent the major source of ROS, producing almost $90 \%$ of total ROS as a consequence of OXPHOS [277]. It is well recognized that ROS accumulation can cause direct damage to organelles and biomolecules (DNA, proteins, and lipids), which, through an inflammatory response, may lead to cancer development [278]. However, to counterbalance ROS overproduction, cells adopt not only enzymatic antioxidants, such as superoxide dismutase (SOD), catalase (CAT), glutathione peroxidases (GPxs), and thioredoxin (Trx) but also nonenzymatic antioxidants, which jointly minimize oxidative stress [279]. 
In cancer cells, an increased metabolic rate, the dysfunction of mitochondria, and activation of oncogenes (e.g., c-Myc, Kras, and BRCA1) are thought to be some of the factors responsible for ROS production [280-283].

ROS support tumor cells in several cancer-related mechanisms, such as survival, angiogenesis, and metastasis [284-286]. Interestingly, conflicting roles of ROS as crucial secondary messengers in cancer and during cancer chemotherapy have emerged [286,287]. Indeed, a growing body of evidence supports the role of ROS not only as a tumor promoter but also as a tumor suppressor [288] in view of the fact that most chemotherapy, radiotherapy, and photodynamic therapy approaches increase intracellular levels of ROS to trigger cancer cell death [289].

In this context, anthracyclines, such as doxorubicin, daunorubicin, and epirubicin, produce the highest ROS levels [290]. Platinum complexes, alkylating agents, camptothecins, and topoisomerase inhibitors also induce the production of high amounts of cellular ROS [291-293]. In contrast, vinca alkaloids, taxanes, and antimetabolites (antifolates and nucleosides) lead to lower levels of ROS [289]. Mitochondrial ROS generation and inhibition of the antioxidant system represent the main reasons for elevated ROS levels. For instance, arsenic trioxide, used in leukemia treatment, provokes mitochondrial membrane potential reduction and inhibition of complexes I and II of the electron transport chain (ETC), triggering ROS overproduction [294,295].

Imexon, a prooxidant small molecule, binds to glutathione (GSH) and cysteine, causing a decrease in the level of cellular GSH and causing the accumulation of ROS in patients with metastatic cancer [296]. The anticancer activity and safety of imexon in leukemia have been confirmed in preclinical and phase I/II clinical trial studies [297]. Mangafodipir inhibits $\mathrm{SOD}$, leading to an increase in $\mathrm{H}_{2} \mathrm{O}_{2}$ levels that triggers apoptosis in cancer cells [298].

Cisplatin, one of the most effective and widely used chemotherapeutic drugs, is known to provoke DNA adducts that, if not repaired, cause DNA damage, leading to ROS generation [299]. Interestingly, Marullo et al. demonstrated that exposure to cisplatin stimulates a mitochondrion-dependent ROS response that boosts its cytotoxic effect towards cancer cells [300].

Even though most chemotherapeutic drugs increase ROS to cytotoxic levels, in cancer cells, such ROS exposure may also minimize chemotherapy effects in the long term, thereby causing chemoresistance [287,301,302].

Notably, resistance to chemotherapeutic drugs is among the leading causes of cancerrelated death [303]. It has been reported that 2-deoxy-D-glucose (2-DG) is able to promote chemoresistance through ROS-stimulated upregulation of P-glycoprotein expression (Pgp) $[304,305]$. In addition, 2-DG may also induce chemoresistance in human ovarian and breast cancer cells by upregulating the expression of dihydrodiol dehydrogenases (DDHs) [306]. Rimessi et al. demonstrated that oxidative stress triggers PKC $\zeta$ accumulation within the nucleus and reduced the sensitivity of cancer cells to chemotherapeutic agents, confirming that this PKC isoform may serve as a useful target for tumor cell chemosensitization [272] (Table 1).

Tumor heterogeneity plays a key role in chemotherapeutic drug resistance [301]. Given that, heterogeneity has been noted to be tightly correlated with high levels of ROS [307].

However, ROS involvement in tumor heterogeneity still requires further investigation. In this scenario, increasing evidence suggests that CSCs co-occur, at least in part, in the emergence of cancer heterogeneity [301].

Especially in recent decades, CSCs have gained growing attention since they are a subset of cancer cells with stemness characteristics that have been detected in several tumors, such as leukemia [308], breast cancer [309], and pancreatic cancer [310]. For this reason, CSCs appear to be responsible for cancer recurrence after chemotherapy or radiotherapy [311]. 
Table 1. Effects and targets of chemotherapeutic drugs on mitochondrial and cellular oxidative stress.

\begin{tabular}{|c|c|c|c|}
\hline Chemotherapeutic Drug & Target & Effect & References \\
\hline $\begin{array}{l}\text { Anthracyclines: Doxorubicin, } \\
\text { Epirubicin, and Daunorubicin }\end{array}$ & Topoisomerase II & $\uparrow \operatorname{ROS}$ & [290] \\
\hline Doxorubicin & $\begin{array}{l}\text { Electron transport system } \\
\text { (ETS) }\end{array}$ & & [289] \\
\hline $\begin{array}{c}\text { Alkylating agents, camptothecins, and } \\
\text { topoisomerase inhibitors } \\
\text { Vinca alkaloids, Taxanes, and }\end{array}$ & $\begin{array}{c}\text { DNA } \\
\text { topoisomerase I }\end{array}$ & $\uparrow \operatorname{ROS}$ & [291-293] \\
\hline $\begin{array}{c}\text { Antimetabolites (antifolates and } \\
\text { nucleoside) }\end{array}$ & Cytoskeleton, $\beta$-tubulin & $\downarrow$ ROS & [289] \\
\hline Arsenic trioxide & Complexes I and II of the ETC & $\downarrow \Delta \Psi \mathrm{m} \uparrow \mathrm{ROS}$ & {$[294,295]$} \\
\hline Imexon & GSH and cysteine & $\downarrow \mathrm{GSH} \uparrow \mathrm{ROS}$ & [296] \\
\hline Mangafodipir & SOD & $\begin{array}{c}\text { Increase in } \mathrm{H}_{2} \mathrm{O}_{2} \text { levels that } \\
\text { trigger apoptosis }\end{array}$ & [298] \\
\hline Cisplatin & DNA & $\begin{array}{l}\text { DNA adducts, and } \\
\text { ROS generation }\end{array}$ & [299] \\
\hline 2-deoxy-D-glucose (2-DG) & $\begin{array}{l}\uparrow \mathrm{P}-\mathrm{gp} \\
\uparrow \mathrm{DDHs}\end{array}$ & $\begin{array}{l}\text { Chemoresistance } \\
\uparrow \text { ROS } \\
\text { Chemoresistance }\end{array}$ & [304-306] \\
\hline
\end{tabular}

$\uparrow:$ represents the increased production, in the case of ROS, or increased expression levels of P-gp or DDHs. $\downarrow$ : represents the decrease in ROS production or mitochondrial membrane potential $(\triangle \Psi \mathrm{m})$, or decreased expression levels of GSH.

In murine and human breast, CSCs have been detected to have a lower level of ROS than their corresponding nontumorigenic cells, which was correlated with higher expression of free radical scavenging system components. Hence, this indicates that enhanced ROS defenses may be responsible for tumor radioresistance [312].

Similarly, Phillips et al. demonstrated that breast CSCs were radiotherapy-resistant and displayed low levels of ROS [313].

Hence, it would be advantageous to develop new delivery strategies, such as nanoparticle delivery systems, to be applied in the clinic to boost and maintain ROS levels for a certain period of time to reverse drug resistance [287].

In the context of chemoresistance, metabolic reprogramming has gained substantial consideration and is now considered a cancer hallmark [314]. These metabolic alterations, some more glycolysis-oriented and some more oxidant-oriented are adopted by cancer cells to overcome stress conditions such as hypoxia or limited nutrients. In addition, these different bioenergetic features may coexist within the same tumor mass (tumor heterogeneity), leading to different responses to chemotherapy [315]. In addition to glycolysis and OXPHOS, it is well documented that most cancer cells are also avidly dependent on glutamine supply, which is referred to as "glutamine addiction" [316,317].

For years, tumor cells have been considered to be more reliant on glycolysis (the "Warburg effect") than normal cells and are characterized by dysfunctional mitochondria [318].

However, in recent years, the importance of OXPHOS in many cancer settings has been increasingly reported, highlighting the different metabolic requirements of cancer cells [319].

High-grade serous ovarian cancer (HGSOC) is one of the most aggressive ovarian cancers and has been reported by Gentric and collaborators to display the highest metabolic heterogeneity. They identified two distinct cellular subgroups, low OXPHOS (relying on glycolysis) and high OXPHOS (relying on OXPHOS, glutamine, and fatty acid oxidation). Interestingly, high-OXPHOS HGSOC exhibited chronic oxidative stress that stimulated the activation of PGC1 $\alpha$. Active PGC1 $\alpha$ enhanced the synthesis of ETC complexes, promoting mitochondrial respiration and thus leading to an increased response to conventional chemotherapies [320]. In contrast, in another study, it was reported that cisplatin-resistant HGSOC cells relied on OXPHOS more than their sensitive counterparts and that inhibition of OXPHOS restored cisplatin sensitivity [321]. 
Furthermore, it has been demonstrated that reduced expression of the mitochondrial chaperone tumor necrosis factor-associated protein (TRAP1), which is known to have a pivotal role in metabolic rewiring, mediates a shift towards OXPHOS, which causes ovarian cancer resistance to cisplatin treatment [322].

Conversely, in a recent study, it was demonstrated that in ovarian cancer cells, MICU1 increases aerobic glycolysis and thus chemoresistance [323].

Additionally, melanomas exhibit unexpected metabolic features. Indeed, it has been reported that this highly aggressive type of cancer develops alternative metabolic strategies to survive and proliferate [324]. Lim and coworkers demonstrated that a subset of human melanomas depend on OXPHOS and that PGC1 $\alpha$ overexpression in these cells facilitates resistance to oxidative stress. Intriguingly, the inhibition of PGC1 $\alpha$ triggers ROS overproduction, HIF1 $\alpha$ stabilization, and a metabolic switch towards glycolysis. Subsequently, suppression of both PGC1 $\alpha$ and HIF1 $\alpha$ causes energetic defects that lead to the emergence of a compensatory mechanism based on the use of glutamine to survive.

Hence, this evidence demonstrates that three alternative metabolic strategies ensure tumor resistance and survival and that combinatorial therapy is required [324].

Similarly, HCC, pancreatic, and colon cancer cells rely on OXPHOS to survive [325-327]. Hence, the usage of OXPHOS inhibitors could be a promising strategy to overcome tumor resistance [326]. As mentioned above, oxidative stress and metabolic remodeling of cancer cells are strongly associated with cancer chemoresistance, in which mitochondria play a fundamental role. Combinatory therapeutic approaches aimed at targeting different metabolic pathways, such as glycolysis, OXPHOS, and even glutaminolysis, could represent a promising strategy for preventing chemoresistance. In addition, exploiting ROS-modulating treatment to eliminate cancer cells and CSCs could strengthen the efficacy of traditional anticancer therapies.

\section{Conclusions}

Chemoresistance, as a survival strategy engaged by cancer cells upon apoptotic stimulation, is inevitably connected to mitochondrion-related pathways. Mitochondria are essential players in cancer cell survival, as they play roles in processes from metabolism to $\mathrm{Ca}^{2+}$ signaling and from mitochondrial dynamics regulation to oxidative stress. Since successful therapies are still needed, it is important to obtain a deeper knowledge of the connections between the players of mitochondria-related pathways.

In fact, current evidence indicates that mitochondria dynamics, which can be both positive and negative regulators of chemoresistance depending on activation timing, cancer cell type, and most importantly, tumor microenvironment, can be considered a potent regulator of cancer drug resistance and thus are potentially crucial targets.

In addition, metabolism-targeted approaches centered on OXPHOS, glutamine metabolism, or ROS might represent successful strategies for inhibiting both cancer proliferation and drug resistance.

Mitochondrial $\mathrm{Ca}^{2+}$ signaling, which is directly modulated by proteins embedded either in the OMM or IMM and/or cytosolic proteins associated with mitochondria, might represent other compelling targets for successful cancer treatment. However, broader characterization of these proteins and their relationship to tumorigenesis and cancer drug resistance through mitochondrial $\mathrm{Ca}^{2+}$ homeostasis regulation is still required.

Taken together, the advancements in the characterization of tumorigenesis and chemoresistance in the context of mitochondrial functionality are not only interesting but also crucial to the understanding of cancer mechanisms and for designing optimal therapeutics against uncontrolled cell survival and resistance to apoptotic stimuli.

Author Contributions: Conceptualization, I.G. and C.G.; resources, P.P. and C.G.; writing-original draft preparation, I.G., M.C., L.M.; writing-review and editing, I.G., M.C., L.M., C.G., G.A.; funding acquisition, P.P., C.G. All authors have read and agreed to the published version of the manuscript. 
Funding: The work is supported by the Italian Association for Cancer Research (AIRC) (IG19803 to C.G. and IG23670 to P.P.), A-ROSE, Progetti di Rilevante Interesse Nazionale (PRIN20177E9EPY to C.G. and PRIN2017E5L5P3 to P.P.), and local funds from the University of Ferrara to PP and CG. I.G. is supported by a research fellowship (AIRC “Acqua Vitasnella” ID: 22552).

Institutional Review Board Statement: Not applicable.

Informed Consent Statement: Not applicable.

Acknowledgments: P.P. is grateful to Camilla degli Scrovegni for continuous support.

Conflicts of Interest: The authors declare no conflict of interest.

\section{References}

1. Longley, D.B.; Johnston, P.G. Molecular Mechanisms of Drug Resistance. J. Pathol. 2005, 205, 275-292. [CrossRef]

2. Holohan, C.; Van Schaeybroeck, S.; Longley, D.B.; Johnston, P.G. Cancer Drug Resistance: An Evolving Paradigm. Nat. Rev. Cancer 2013, 13, 714-726. [CrossRef] [PubMed]

3. Housman, G.; Byler, S.; Heerboth, S.; Lapinska, K.; Longacre, M.; Snyder, N.; Sarkar, S. Drug Resistance in Cancer: An Overview. Cancers 2014, 6, 1769-1792. [CrossRef]

4. Payandeh, Z.; Pirpour Tazehkand, A.; Barati, G.; Pouremamali, F.; Kahroba, H.; Baradaran, B.; Samadi, N. Role of Nrf2 and Mitochondria in Cancer Stem Cells; in Carcinogenesis, Tumor Progression, and Chemoresistance. Biochimie 2020, 179, 32-45. [CrossRef] [PubMed]

5. Duan, H.; Liu, Y.; Gao, Z.; Huang, W. Recent Advances in Drug Delivery Systems for Targeting Cancer Stem Cells. Acta Pharm. Sin. B 2021, 11, 55-70. [CrossRef]

6. García-Heredia, J.M.; Carnero, A. Role of Mitochondria in Cancer Stem Cell Resistance. Cells 2020, 9, 1693. [CrossRef]

7. Kahroba, H.; Shirmohamadi, M.; Hejazi, M.S.; Samadi, N. The Role of Nrf2 Signaling in Cancer Stem Cells: From Stemness and Self-renewal to Tumorigenesis and Chemoresistance. Life Sci. 2019, 239, 116986. [CrossRef]

8. Yan, C.; Li, T.-S. Dual Role of Mitophagy in Cancer Drug Resistance. Anticancer Res. 2018, 38, 617-621. [CrossRef]

9. Rich, J.N. Cancer Stem Cells: Understanding Tumor Hierarchy and Heterogeneity. Medicine 2016, 95, S2-S7. [CrossRef] [PubMed]

10. O’Brien, C.A.; Kreso, A.; Dick, J.E. Cancer Stem Cells in Solid Tumors: An Overview. Semin. Radiat. Oncol. 2009, 19, 71-77. [CrossRef]

11. Yang, L.; Shi, P.; Zhao, G.; Xu, J.; Peng, W.; Zhang, J.; Zhang, G.; Wang, X.; Dong, Z.; Chen, F.; et al. Targeting Cancer Stem Cell Pathways for Cancer Therapy. Signal Transduct. Target Ther. 2020, 5, 8. [CrossRef]

12. Hu, Y.; Fu, L. Targeting Cancer Stem Cells: A New Therapy to Cure Cancer Patients. Am. J. Cancer Res. $2012,2,340-356$.

13. Vlashi, E.; Lagadec, C.; Vergnes, L.; Matsutani, T.; Masui, K.; Poulou, M.; Popescu, R.; Della Donna, L.; Evers, P.; Dekmezian, C.; et al. Metabolic State of Glioma Stem Cells and Nontumorigenic Cells. Proc. Natl. Acad. Sci. USA 2011, $108,16062-16067$. [CrossRef] [PubMed]

14. Blagosklonny, M.V. Carcinogenesis, Cancer Therapy and Chemoprevention. Cell Death Differ. 2005, 12, 592-602. [CrossRef]

15. Jagust, P.; de Luxán-Delgado, B.; Parejo-Alonso, B.; Sancho, P. Metabolism-Based Therapeutic Strategies Targeting Cancer Stem Cells. Front. Pharmacol. 2019, 10, 203. [CrossRef]

16. Ito, K.; Suda, T. Metabolic Requirements for the Maintenance of Self-renewing Stem Cells. Nat. Rev. Mol. Cell Biol. 2014, 15, 243-256. [CrossRef]

17. Faubert, B.; Solmonson, A.; DeBerardinis, R.J. Metabolic Reprogramming and Cancer Progression. Science 2020, 368. [CrossRef] [PubMed]

18. Genovese, I.; Vezzani, B.; Danese, A.; Modesti, L.; Vitto, V.A.M.; Corazzi, V.; Pelucchi, S.; Pinton, P.; Giorgi, C. Mitochondria as the Decision Makers for Cancer Cell Fate: From Signaling Pathways to Therapeutic Strategies. Cell Calcium 2020, $92,102308$. [CrossRef]

19. Alptekin, A.; Ye, B.; Ding, H.-F. Transcriptional Regulation of Stem Cell and Cancer Stem Cell Metabolism. Curr. Stem Cell Rep. 2017, 3, 19-27. [CrossRef] [PubMed]

20. Guha, M.; Srinivasan, S.; Ruthel, G.; Kashina, A.K.; Carstens, R.P.; Mendoza, A.; Khanna, C.; Van Winkle, T.; Avadhani, N.G. Mitochondrial Retrograde Signaling Induces Epithelial-mesenchymal Transition and Generates Breast Cancer Stem Cells. Oncogene 2014, 33, 5238-5250. [CrossRef]

21. Missiroli, S.; Perrone, M.; Genovese, I.; Pinton, P.; Giorgi, C. Cancer Metabolism and Mitochondria: Finding Novel Mechanisms to Fight Tumours. EBioMedicine 2020, 59, 102943. [CrossRef]

22. Marchi, S.; Giorgi, C.; Galluzzi, L.; Pinton, P. Ca ${ }^{2+}$ Fluxes and Cancer. Mol. Cell 2020, 78, 1055-1069. [CrossRef] [PubMed]

23. Danese, A.; Marchi, S.; Vitto, V.A.M.; Modesti, L.; Leo, S.; Wieckowski, M.R.; Giorgi, C.; Pinton, P. Cancer-Related Increases and Decreases in Calcium Signaling at the Endoplasmic Reticulum-Mitochondria Interface (MAMs). Rev. Physiol. Biochem. Pharmacol. 2020. [CrossRef]

24. Missiroli, S.; Genovese, I.; Perrone, M.; Vezzani, B.; Vitto, V.A.M.; Giorgi, C. The Role of Mitochondria in Inflammation: From Cancer to Neurodegenerative Disorders. J. Clin. Med. 2020, 9, 740. [CrossRef] [PubMed] 
25. Patergnani, S.; Danese, A.; Bouhamida, E.; Aguiari, G.; Previati, M.; Pinton, P.; Giorgi, C. Various Aspects of Calcium Signaling in the Regulation of Apoptosis, Autophagy, Cell Proliferation, and Cancer. Int. J. Mol. Sci. 2020, 21, 8323. [CrossRef]

26. Rimessi, A.; Pedriali, G.; Vezzani, B.; Tarocco, A.; Marchi, S.; Wieckowski, M.R.; Giorgi, C.; Pinton, P. Interorganellar Calcium Signaling in the Regulation of Cell Metabolism: A Cancer Perspective. Semin. Cell Dev. Biol. 2020, 98, 167-180. [CrossRef]

27. Cardenas, C.; Lovy, A.; Silva-Pavez, E.; Urra, F.; Mizzoni, C.; Ahumada-Castro, U.; Bustos, G.; Jaňa, F.; Cruz, P.; Farias, P.; et al. Cancer Cells with Defective Oxidative Phosphorylation Require Endoplasmic Reticulum-to-mitochondria Ca ${ }^{2+} \mathrm{Transfer} \mathrm{for}$ Survival. Sci. Signal. 2020, 13. [CrossRef]

28. Roushandeh, A.M.; Tomita, K.; Kuwahara, Y.; Jahanian-Najafabadi, A.; Igarashi, K.; Roudkenar, M.H.; Sato, T. Transfer of Healthy Fibroblast-derived Mitochondria to HeLa $\rho 0$ and SAS $\rho 0$ Cells Recovers the Proliferation Capabilities of These Cancer Cells under Conventional Culture Medium, but Increase Their Sensitivity to Cisplatin-induced Apoptotic Death. Mol. Biol. Rep. 2020, 47, 4401-4411. [CrossRef]

29. Zampieri, L.X.; Grasso, D.; Bouzin, C.; Brusa, D.; Rossignol, R.; Sonveaux, P. Mitochondria Participate in Chemoresistance to Cisplatin in Human Ovarian Cancer Cells. Mol. Cancer Res. 2020, 18, 1379-1391. [CrossRef]

30. Chan, D.C. Mitochondrial Fusion and Fission in Mammals. Annu. Rev. Cell Dev. Biol. 2006, 22, 79-99. [CrossRef]

31. Wai, T.; Langer, T. Mitochondrial Dynamics and Metabolic Regulation. Trends Endocrinol. Metab. 2016, 27, 105-117. [CrossRef] [PubMed]

32. Mishra, P.; Chan, D.C. Metabolic Regulation of Mitochondrial Dynamics. J. Cell Biol. 2016, 212, 379-387. [CrossRef]

33. Cho, D.-H.; Nakamura, T.; Lipton, S.A. Mitochondrial Dynamics in Cell Death and Neurodegeneration. Cell. Mol. Life Sci. 2010, 67, 3435-3447. [CrossRef] [PubMed]

34. Carinci, M.; Vezzani, B.; Patergnani, S.; Ludewig, P.; Lessmann, K.; Magnus, T.; Casetta, I.; Pugliatti, M.; Pinton, P.; Giorgi, C. Different Roles of Mitochondria in Cell Death and Inflammation: Focusing on Mitochondrial Quality Control in Ischemic Stroke and Reperfusion. Biomedicines 2021, 9, 169. [CrossRef]

35. Maycotte, P.; Marín-Hernández, A.; Goyri-Aguirre, M.; Anaya-Ruiz, M.; Reyes-Leyva, J.; Cortés-Hernández, P. Mitochondrial dynamics and cancer. Tumour Biol. 2017, 39. [CrossRef] [PubMed]

36. Archer, S.L. Mitochondrial Dynamics-Mitochondrial Fission and Fusion in Human Diseases. N. Engl. J. Med. 2013, 369, $2236-2251$. [CrossRef]

37. Zhao, J.; Zhang, J.; Yu, M.; Xie, Y.; Huang, Y.; Wolff, D.W.; Abel, P.W.; Tu, Y. Mitochondrial Dynamics Regulates Migration and Invasion of Breast Cancer Cells. Oncogene 2013, 32, 4814-4824. [CrossRef]

38. Chen, H.; Chan, D.C. Mitochondrial Dynamics in Regulating the Unique Phenotypes of Cancer and Stem Cells. Cell Metab. 2017, 26, 39-48. [CrossRef]

39. Tilokani, L.; Nagashima, S.; Paupe, V.; Prudent, J. Mitochondrial Dynamics: Overview of Molecular Mechanisms. Essays Biochem. 2018, 62, 341-360. [CrossRef]

40. Arakaki, N.; Nishihama, T.; Owaki, H.; Kuramoto, Y.; Suenaga, M.; Miyoshi, E.; Emoto, Y.; Shibata, H.; Shono, M.; Higuti, T. Dynamics of Mitochondria during the Cell Cycle. Biol. Pharm. Bull. 2006, 29, 1962-1965. [CrossRef]

41. Ishihara, N.; Nomura, M.; Jofuku, A.; Kato, H.; Suzuki, S.O.; Masuda, K.; Otera, H.; Nakanishi, Y.; Nonaka, I.; Goto, Y.-I.; et al. Mitochondrial Fission Factor Drp1 is Essential for Embryonic Development and Synapse Formation in Mice. Nat. Cell Biol. 2009, 11, 958-966. [CrossRef] [PubMed]

42. Youle, R.J.; Karbowski, M. Mitochondrial Fission in Apoptosis. Nat. Rev. Mol. Cell Biol. 2005, 6, 657-663. [CrossRef]

43. Quintana-Cabrera, R.; Quirin, C.; Glytsou, C.; Corrado, M.; Urbani, A.; Pellattiero, A.; Calvo, E.; Vázquez, J.; Enríquez, J.A.; Gerle, C.; et al. The Cristae Modulator Optic Atrophy 1 Requires Mitochondrial ATP Synthase Oligomers to Safeguard Mitochondrial Function. Nat. Commun. 2018, 9, 3399. [CrossRef]

44. van der Bliek, A.M.; Shen, Q.; Kawajiri, S. Mechanisms of Mitochondrial Fission and Fusion. Cold Spring Harb. Perspect. Biol. 2013, 5. [CrossRef]

45. Skulachev, V.P. Mitochondrial Filaments and Clusters as Intracellular Power-transmitting Cables. Trends Biochem. Sci. 2001, 26, 23-29. [CrossRef]

46. Rambold, A.S.; Kostelecky, B.; Elia, N.; Lippincott-Schwartz, J. Tubular Network Formation Protects Mitochondria from Autophagosomal Degradation during Nutrient Starvation. Proc. Natl. Acad. Sci. USA 2011, 108, 10190-10195. [CrossRef] [PubMed]

47. Youle, R.J.; van der Bliek, A.M. Mitochondrial Fission, Fusion, and Stress. Science 2012, 337, 1062-1065. [CrossRef]

48. Lee, Y.; Jeong, S.-Y.; Karbowski, M.; Smith, C.L.; Youle, R.J. Roles of the Mammalian Mitochondrial Fission and Fusion Mediators Fis1, Drp1, and Opa1 in Apoptosis. Mol. Biol. Cell 2004, 15, 5001-5011. [CrossRef]

49. Taguchi, N.; Ishihara, N.; Jofuku, A.; Oka, T.; Mihara, K. Mitotic Phosphorylation of Dynamin-related GTPase Drp1 Participates in Mitochondrial Fission. J. Biol. Chem. 2007, 282, 11521-11529. [CrossRef]

50. Burman, J.L.; Pickles, S.; Wang, C.; Sekine, S.; Vargas, J.N.S.; Zhang, Z.; Youle, A.M.; Nezich, C.L.; Wu, X.; Hammer, J.A.; et al. Mitochondrial Fission Facilitates the Selective Mitophagy of Protein Aggregates. J. Cell Biol. 2017, 216, 3231-3247. [CrossRef]

51. Ferreira-da-Silva, A.; Valacca, C.; Rios, E.; Pópulo, H.; Soares, P.; Sobrinho-Simões, M.; Scorrano, L.; Máximo, V.; Campello, S. Mitochondrial Dynamics Protein Drp1 is Overexpressed in Oncocytic Thyroid Tumors and Regulates Cancer Cell Migration. PLoS ONE 2015, 10, e0122308. [CrossRef] [PubMed]

52. Westrate, L.M.; Sayfie, A.D.; Burgenske, D.M.; MacKeigan, J.P. Persistent Mitochondrial Hyperfusion Promotes G2/M Accumulation and Caspase-dependent Cell Death. PLoS ONE 2014, 9, e91911. [CrossRef] [PubMed] 
53. Santel, A.; Fuller, M.T. Control of Mitochondrial Morphology by a Human Mitofusin. J. Cell Sci. 2001, 114, 867-874. [CrossRef]

54. Cipolat, S.; Martins de Brito, O.; Dal Zilio, B.; Scorrano, L. OPA1 Requires Mitofusin 1 to Promote Mitochondrial Fusion. Proc. Natl. Acad. Sci. USA 2004, 101, 15927-15932. [CrossRef]

55. Ishihara, N.; Eura, Y.; Mihara, K. Mitofusin 1 and 2 play distinct roles in mitochondrial fusion reactions via GTPase activity. J. Cell Sci. 2004, 117, 6535-6546. [CrossRef]

56. Cao, Y.-L.; Meng, S.; Chen, Y.; Feng, J.-X.; Gu, D.-D.; Yu, B.; Li, Y.-J.; Yang, J.-Y.; Liao, S.; Chan, D.C.; et al. MFN1 Structures Reveal Nucleotide-triggered Dimerization Critical for Mitochondrial Fusion. Nature 2017, 542, 372-376. [CrossRef] [PubMed]

57. Hoppins, S.; Nunnari, J. The Molecular Mechanism of Mitochondrial Fusion. Biochim. Biophys. Acta 2009, 1793, 20-26. [CrossRef] [PubMed]

58. Ehses, S.; Raschke, I.; Mancuso, G.; Bernacchia, A.; Geimer, S.; Tondera, D.; Martinou, J.-C.; Westermann, B.; Rugarli, E.I.; Langer, T. Regulation of OPA1 Processing and Mitochondrial Fusion by m-AAA Protease Isoenzymes and OMA1. J. Cell Biol. 2009, 187, 1023-1036. [CrossRef]

59. Head, B.; Griparic, L.; Amiri, M.; Gandre-Babbe, S.; van der Bliek, A.M. Inducible Proteolytic Inactivation of OPA1 Mediated by the OMA1 Protease in Mammalian Cells. J. Cell Biol. 2009, 187, 959-966. [CrossRef]

60. Ishihara, N.; Fujita, Y.; Oka, T.; Mihara, K. Regulation of Mitochondrial Morphology through Proteolytic Cleavage of OPA1. EMBO J. 2006, 25, 2966-2977. [CrossRef]

61. Song, Z.; Chen, H.; Fiket, M.; Alexander, C.; Chan, D.C. OPA1 Processing Controls Mitochondrial Fusion and is Regulated by mRNA Splicing, Membrane Potential, and Yme1L. J. Cell Biol. 2007, 178, 749-755. [CrossRef]

62. Anand, R.; Wai, T.; Baker, M.J.; Kladt, N.; Schauss, A.C.; Rugarli, E.; Langer, T. The i-AAA Protease YME1L and OMA1 Cleave OPA1 to Balance Mitochondrial Fusion and Fission. J. Cell Biol. 2014, 204, 919-929. [CrossRef] [PubMed]

63. Duvezin-Caubet, S.; Jagasia, R.; Wagener, J.; Hofmann, S.; Trifunovic, A.; Hansson, A.; Chomyn, A.; Bauer, M.F.; Attardi, G.; Larsson, N.-G.; et al. Proteolytic Processing of OPA1 Links Mitochondrial Dysfunction to Alterations in Mitochondrial Morphology. J. Biol. Chem. 2006, 281, 37972-37979. [CrossRef] [PubMed]

64. Wai, T.; García-Prieto, J.; Baker, M.J.; Merkwirth, C.; Benit, P.; Rustin, P.; Rupérez, F.J.; Barbas, C.; Ibañez, B.; Langer, T. Imbalanced OPA1 Processing and Mitochondrial Fragmentation Cause Heart Failure in Mice. Science 2015, 350, aad0116. [CrossRef] [PubMed]

65. Kong, B.; Wang, Q.; Fung, E.; Xue, K.; Tsang, B.K. p53 is Required for Cisplatin-induced Processing of the Mitochondrial Fusion Protein L-Opa1 That is Mediated by the Mitochondrial Metallopeptidase Oma1 in Gynecologic Cancers. J. Biol. Chem. 2014, 289, 27134-27145. [CrossRef] [PubMed]

66. Kingnate, C.; Charoenkwan, K.; Kumfu, S.; Chattipakorn, N.; Chattipakorn, S.C. Possible Roles of Mitochondrial Dynamics and the Effects of Pharmacological Interventions in Chemoresistant Ovarian Cancer. EBioMedicine 2018, 34, 256-266. [CrossRef]

67. Kong, B.; Tsuyoshi, H.; Orisaka, M.; Shieh, D.-B.; Yoshida, Y.; Tsang, B.K. Mitochondrial Dynamics Regulating Chemoresistance in Gynecological Cancers. Ann. N. Y. Acad. Sci. 2015, 1350, 1-16. [CrossRef]

68. Chen, X.; Glytsou, C.; Zhou, H.; Narang, S.; Reyna, D.E.; Lopez, A.; Sakellaropoulos, T.; Gong, Y.; Kloetgen, A.; Yap, Y.S.; et al. Targeting Mitochondrial Structure Sensitizes Acute Myeloid Leukemia to Venetoclax Treatment. Cancer Discov. 2019, 9, 890-909. [CrossRef] [PubMed]

69. Decker, C.W.; Garcia, J.; Gatchalian, K.; Arceneaux, D.; Choi, C.; Han, D.; Hernandez, J.B. Mitofusin-2 mediates Doxorubicin Sensitivity and Acute Resistance in Jurkat Leukemia Cells. Biochem. Biophys. Rep. 2020, 24, 100824. [CrossRef]

70. Casinelli, G.; LaRosa, J.; Sharma, M.; Cherok, E.; Banerjee, S.; Branca, M.; Edmunds, L.; Wang, Y.; Sims-Lucas, S.; Churley, L.; et al. N-Myc Overexpression Increases Cisplatin Resistance in Neuroblastoma via Deregulation of Mitochondrial Dynamics. Cell Death Discov. 2016, 2, 16082. [CrossRef] [PubMed]

71. Chan, D.C. Fusion and Fission: Interlinked Processes Critical for Mitochondrial Health. Annu. Rev. Genet. 2012, 46, 265-287. [CrossRef] [PubMed]

72. Smirnova, E.; Griparic, L.; Shurland, D.L.; van der Bliek, A.M. Dynamin-related Protein Drp1 is Required for Mitochondrial Division in Mammalian Cells. Mol. Biol. Cell 2001, 12, 2245-2256. [CrossRef]

73. Qi, X.; Disatnik, M.-H.; Shen, N.; Sobel, R.A.; Mochly-Rosen, D. Aberrant Mitochondrial Fission in Neurons Induced by Protein Kinase C\{delta\} under Oxidative Stress Conditions in vivo. Mol. Biol. Cell 2011, 22, 256-265. [CrossRef]

74. Yu, T.; Jhun, B.S.; Yoon, Y. High-glucose Stimulation Increases Reactive Oxygen Species Production through the Calcium and Mitogen-activated Protein Kinase-mediated Activation of Mitochondrial Fission. Antioxid. Redox Signal. 2011, 14, 425-437. [CrossRef]

75. Suzuki, M.; Yamakawa, T.; Suzuki, A. A Micro Method Involving Micro High-performance Liquid Chromatography-mass Spectrometry for the Structural Characterization of Neutral Glycosphingolipids and Monosialogangliosides. J. Biochem. 1991, 109, 503-506. [CrossRef] [PubMed]

76. Toyama, E.Q.; Herzig, S.; Courchet, J.; Lewis, T.L.; Losón, O.C.; Hellberg, K.; Young, N.P.; Chen, H.; Polleux, F.; Chan, D.C.; et al. Metabolism. AMP-activated Protein Kinase Mediates Mitochondrial Fission in Response to Energy Stress. Science 2016, 351, 275-281. [CrossRef]

77. Cribbs, J.T.; Strack, S. Reversible Phosphorylation of Drp1 by Cyclic AMP-dependent Protein Kinase and Calcineurin Regulates Mitochondrial Fission and Cell Death. EMBO Rep. 2007, 8, 939-944. [CrossRef] [PubMed]

78. Rodrigues, T.; Ferraz, L.S. Therapeutic Potential of Targeting Mitochondrial Dynamics in Cancer. Biochem. Pharmacol. 2020, 182, 114282. [CrossRef] 
79. Xie, L.; Shi, F.; Li, Y.; Li, W.; Yu, X.; Zhao, L.; Zhou, M.; Hu, J.; Luo, X.; Tang, M.; et al. Drp1-dependent Remodeling of Mitochondrial Morphology Triggered by EBV-LMP1 Increases Cisplatin Resistance. Signal Transduct. Target Ther. $2020,5,56$. [CrossRef] [PubMed]

80. Takam Kamga, P.; Bassi, G.; Cassaro, A.; Midolo, M.; Di Trapani, M.; Gatti, A.; Carusone, R.; Resci, F.; Perbellini, O.; Gottardi, M.; et al. Notch Signalling Drives Bone Marrow Stromal Cell-mediated Chemoresistance in Acute Myeloid Leukemia. Oncotarget 2016, 7, 21713-21727. [CrossRef]

81. Mistry, D.K.; Cottrell, G.A. Actions of Steroids and Bemegride on the GABAA Receptor of Mouse Spinal Neurones in Culture. Exp. Physiol. 1990, 75, 199-209. [CrossRef]

82. Gorrini, C.; Harris, I.S.; Mak, T.W. Modulation of Oxidative Stress as an Anticancer Strategy. Nat. Rev. Drug Discov. 2013, 12, 931-947. [CrossRef]

83. Cai, J.; Wang, J.; Huang, Y.; Wu, H.; Xia, T.; Xiao, J.; Chen, X.; Li, H.; Qiu, Y.; Wang, Y.; et al. ERK/Drp1-dependent Mitochondrial Fission is Involved in the MSC-induced Drug Resistance of T-cell Acute Lymphoblastic Leukemia Cells. Cell Death Dis. 2016, 7 , e2459. [CrossRef] [PubMed]

84. Han, Y.; Cho, U.; Kim, S.; Park, I.S.; Cho, J.H.; Dhanasekaran, D.N.; Song, Y.S. Tumour Microenvironment on Mitochondrial Dynamics and Chemoresistance in Cancer. Free Radic. Res. 2018, 52, 1271-1287. [CrossRef]

85. Han, Y.; Kim, B.; Cho, U.; Park, I.S.; Kim, S.I.; Dhanasekaran, D.N.; Tsang, B.K.; Song, Y.S. Mitochondrial Fission Causes Cisplatin Resistance under Hypoxic Conditions via ROS in Ovarian Cancer Cells. Oncogene 2019, 38, 7089-7105. [CrossRef]

86. Bordt, E.A.; Clerc, P.; Roelofs, B.A.; Saladino, A.J.; Tretter, L.; Adam-Vizi, V.; Cherok, E.; Khalil, A.; Yadava, N.; Ge, S.X.; et al. The Putative Drp1 Inhibitor mdivi-1 Is a Reversible Mitochondrial Complex I Inhibitor that Modulates Reactive Oxygen Species. Dev. Cell 2017, 40, 583-594.e6. [CrossRef] [PubMed]

87. Dai, W.; Wang, G.; Chwa, J.; Oh, M.E.; Abeywardana, T.; Yang, Y.; Wang, Q.A.; Jiang, L. Mitochondrial Division Inhibitor (mdivi-1) Decreases Oxidative Metabolism in Cancer. Br. J. Cancer 2020, 122, 1288-1297. [CrossRef]

88. Yu, Y.; Xu, L.; Qi, L.; Wang, C.; Xu, N.; Liu, S.; Li, S.; Tian, H.; Liu, W.; Xu, Y.; et al. ABT737 Induces Mitochondrial Pathway Apoptosis and Mitophagy by Regulating DRP1-dependent Mitochondrial Fission in Human Ovarian Cancer Cells. Biomed. Pharmacother. 2017, 96, 22-29. [CrossRef]

89. Huang, C.-Y.; Chiang, S.-F.; Chen, W.T.-L.; Ke, T.-W.; Chen, T.-W.; You, Y.-S.; Lin, C.-Y.; Chao, K.S.C.; Huang, C.-Y. HMGB1 Promotes ERK-mediated Mitochondrial Drp1 Phosphorylation for Chemoresistance through RAGE in Colorectal Cancer. Cell Death Dis. 2018, 9, 1004. [CrossRef]

90. Huang, L.; Luan, T.; Chen, Y.; Bao, X.; Huang, Y.; Fu, S.; Wang, H.; Wang, J. LASS2 Regulates Invasion and Chemoresistance via ERK/Drp1 Modulated Mitochondrial Dynamics in Bladder Cancer Cells. J. Cancer 2018, 9, 1017-1024. [CrossRef]

91. Twig, G.; Shirihai, O.S. The Interplay between Mitochondrial Dynamics and Mitophagy. Antioxid. Redox Signal. 2011, 14, 1939-1951. [CrossRef]

92. Shirihai, O.S.; Song, M.; Dorn, G.W. How Mitochondrial Dynamism Orchestrates Mitophagy. Circ. Res. 2015, 116, 1835-1849. [CrossRef]

93. Lemasters, J.J. Selective Mitochondrial Autophagy, or Mitophagy, as a Targeted Defense against Oxidative Stress, Mitochondrial Dysfunction, and Aging. Rejuvenation Res. 2005, 8, 3-5. [CrossRef]

94. Okatsu, K.; Oka, T.; Iguchi, M.; Imamura, K.; Kosako, H.; Tani, N.; Kimura, M.; Go, E.; Koyano, F.; Funayama, M.; et al. PINK1 Autophosphorylation upon Membrane Potential Dissipation is Essential for Parkin Recruitment to Damaged Mitochondria. Nat. Commun. 2012, 3, 1016. [CrossRef]

95. Kondapalli, C.; Kazlauskaite, A.; Zhang, N.; Woodroof, H.I.; Campbell, D.G.; Gourlay, R.; Burchell, L.; Walden, H.; Macartney, T.J.; Deak, M.; et al. PINK1 is Activated by Mitochondrial Membrane Potential Depolarization and Stimulates Parkin E3 Ligase Activity by Phosphorylating Serine 65. Open Biol. 2012, 2, 120080. [CrossRef]

96. Schubert, A.F.; Gladkova, C.; Pardon, E.; Wagstaff, J.L.; Freund, S.M.V.; Steyaert, J.; Maslen, S.L.; Komander, D. Structure of PINK1 in Complex with Its Substrate Ubiquitin. Nature 2017, 552, 51-56. [CrossRef]

97. Lazarou, M.; Sliter, D.A.; Kane, L.A.; Sarraf, S.A.; Wang, C.; Burman, J.L.; Sideris, D.P.; Fogel, A.I.; Youle, R.J. The Ubiquitin Kinase PINK1 Recruits Autophagy Receptors to Induce Mitophagy. Nature 2015, 524, 309-314. [CrossRef]

98. Novak, I.; Dikic, I. Autophagy Receptors in Developmental Clearance of Mitochondria. Autophagy 2011, 7, 301-303. [CrossRef]

99. Novak, I.; Kirkin, V.; McEwan, D.G.; Zhang, J.; Wild, P.; Rozenknop, A.; Rogov, V.; Löhr, F.; Popovic, D.; Occhipinti, A.; et al. Nix is a Selective Autophagy Receptor for Mitochondrial Clearance. EMBO Rep. 2010, 11, 45-51. [CrossRef]

100. Hanna, R.A.; Quinsay, M.N.; Orogo, A.M.; Giang, K.; Rikka, S.; Gustafsson, Å.B. Microtubule-associated Protein 1 Light Chain 3 (LC3) Interacts with Bnip3 Protein to Selectively Remove Endoplasmic Reticulum and Mitochondria via Autophagy. J. Biol. Chem. 2012, 287, 19094-19104. [CrossRef]

101. Liu, L.; Feng, D.; Chen, G.; Chen, M.; Zheng, Q.; Song, P.; Ma, Q.; Zhu, C.; Wang, R.; Qi, W.; et al. Mitochondrial Outer-membrane Protein FUNDC1 Mediates Hypoxia-induced Mitophagy in Mammalian Cells. Nat. Cell Biol. 2012, 14, 177-185. [CrossRef] [PubMed]

102. Panigrahi, D.P.; Praharaj, P.P.; Bhol, C.S.; Mahapatra, K.K.; Patra, S.; Behera, B.P.; Mishra, S.R.; Bhutia, S.K. The Emerging, Multifaceted Role of Mitophagy in Cancer and Cancer Therapeutics. Semin. Cancer Biol. 2019. [CrossRef]

103. Yang, X.; Yu, D.-D.; Yan, F.; Jing, Y.-Y.; Han, Z.-P.; Sun, K.; Liang, L.; Hou, J.; Wei, L.-X. The Role of Autophagy Induced by Tumor Microenvironment in Different Cells and Stages of Cancer. Cell Biosci. 2015, 5, 14. [CrossRef] 
104. Oun, R.; Moussa, Y.E.; Wheate, N.J. The Side Effects of Platinum-based Chemotherapy Drugs: A Review for Chemists. Dalton Trans. 2018, 47, 6645-6653. [CrossRef]

105. Zhang, R.; Gu, J.; Chen, J.; Ni, J.; Hung, J.; Wang, Z.; Zhang, X.; Feng, J.; Ji, L. High Expression of PINK1 Promotes Proliferation and Chemoresistance of NSCLC. Oncol. Rep. 2017, 37, 2137-2146. [CrossRef]

106. Liu, L.; Zuo, Z.; Lu, S.; Wang, L.; Liu, A.; Liu, X. Silencing of PINK1 Represses Cell Growth, Migration and Induces Apoptosis of Lung Cancer Cells. Biomed. Pharmacother. 2018, 106, 333-341. [CrossRef]

107. Yamashita, K.; Miyata, H.; Makino, T.; Masuike, Y.; Furukawa, H.; Tanaka, K.; Miyazaki, Y.; Takahashi, T.; Kurokawa, Y.; Yamasaki, M.; et al. High Expression of the Mitophagy-Related Protein Pink1 is Associated with a Poor Response to Chemotherapy and a Poor Prognosis for Patients Treated with Neoadjuvant Chemotherapy for Esophageal Squamous Cell Carcinoma. Ann. Surg. Oncol. 2017, 24, 4025-4032. [CrossRef]

108. Yao, N.; Wang, C.; Hu, N.; Li, Y.; Liu, M.; Lei, Y.; Chen, M.; Chen, L.; Chen, C.; Lan, P.; et al. Inhibition of PINK1/Parkin-dependent Mitophagy Sensitizes Multidrug-resistant Cancer Cells to B5G1, a New Betulinic Acid Analog. Cell Death Dis. 2019, 10, 232. [CrossRef]

109. Hou, H.; Er, P.; Cheng, J.; Chen, X.; Ding, X.; Wang, Y.; Chen, X.; Yuan, Z.; Pang, Q.; Wang, P.; et al. High Expression of FUNDC1 Predicts Poor Prognostic Outcomes and is a Promising Target to Improve Chemoradiotherapy Effects in Patients with Cervical Cancer. Cancer Med. 2017, 6, 1871-1881. [CrossRef]

110. Perkons, N.R.; Kiefer, R.M.; Noji, M.C.; Pourfathi, M.; Ackerman, D.; Siddiqui, S.; Tischfield, D.; Profka, E.; Johnson, O.; Pickup S.; et al. Hyperpolarized Metabolic Imaging Detects Latent Hepatocellular Carcinoma Domains Surviving Locoregional Therapy. Hepatology 2020, 72, 140-154. [CrossRef] [PubMed]

111. Zhao, C.; Chen, Z.; Qi, J.; Duan, S.; Huang, Z.; Zhang, C.; Wu, L.; Zeng, M.; Zhang, B.; Wang, N.; et al. Drp1-dependent Mitophagy Protects against Cisplatin-induced Apoptosis of Renal Tubular Epithelial Cells by Improving Mitochondrial Function. Oncotarget 2017, 8, 20988-21000. [CrossRef] [PubMed]

112. Yan, C.; Luo, L.; Guo, C.-Y.; Goto, S.; Urata, Y.; Shao, J.-H.; Li, T.-S. Doxorubicin-induced Mitophagy Contributes to Drug Resistance in Cancer Stem Cells from HCT8 Human Colorectal Cancer Cells. Cancer Lett. 2017, 388, 34-42. [CrossRef]

113. Desir, S.; O’Hare, P.; Vogel, R.I.; Sperduto, W.; Sarkari, A.; Dickson, E.L.; Wong, P.; Nelson, A.C.; Fong, Y.; Steer, C.J.; et al. Chemotherapy-Induced Tunneling Nanotubes Mediate Intercellular Drug Efflux in Pancreatic Cancer. Sci. Rep. 2018, 8, 9484. [CrossRef]

114. Lim, P.K.; Bliss, S.A.; Patel, S.A.; Taborga, M.; Dave, M.A.; Gregory, L.A.; Greco, S.J.; Bryan, M.; Patel, P.S.; Rameshwar, P. Gap Junction-mediated Import of microRNA from Bone Marrow Stromal Cells Can Elicit Cell Cycle Quiescence in Breast Cancer Cells. Cancer Res. 2011, 71, 1550-1560. [CrossRef] [PubMed]

115. Nawaz, M.; Camussi, G.; Valadi, H.; Nazarenko, I.; Ekström, K.; Wang, X.; Principe, S.; Shah, N.; Ashraf, N.M.; Fatima, F.; et al. The Emerging Role of Extracellular Vesicles as Biomarkers for Urogenital Cancers. Nat. Rev. Urol. 2014, 11, 688-701. [CrossRef]

116. Rustom, A.; Saffrich, R.; Markovic, I.; Walther, P.; Gerdes, H.-H. Nanotubular Highways for Intercellular Organelle Transport. Science 2004, 303, 1007-1010. [CrossRef]

117. Zhang, J.; Whitehead, J.; Liu, Y.; Yang, Q.; Leach, J.K.; Liu, G.-Y. Direct Observation of Tunneling Nanotubes within Human Mesenchymal Stem Cell Spheroids. J. Phys. Chem. B 2018, 122, 9920-9926. [CrossRef]

118. Pegtel, D.M.; Peferoen, L.; Amor, S. Extracellular Vesicles as Modulators of Cell-to-cell Communication in the Healthy and Diseased Brain. Philos. Trans. R. Soc. B Biol. Sci. 2014, 369. [CrossRef]

119. Paolicelli, R.C.; Bergamini, G.; Rajendran, L. Cell-to-cell Communication by Extracellular Vesicles: Focus on Microglia. Neuroscience 2019, 405, 148-157. [CrossRef]

120. Vignais, M.-L.; Caicedo, A.; Brondello, J.-M.; Jorgensen, C. Cell Connections by Tunneling Nanotubes: Effects of Mitochondrial Trafficking on Target Cell Metabolism, Homeostasis, and Response to Therapy. Stem Cells Int. 2017, 2017, 6917941. [CrossRef]

121. Ahmad, T.; Mukherjee, S.; Pattnaik, B.; Kumar, M.; Singh, S.; Kumar, M.; Rehman, R.; Tiwari, B.K.; Jha, K.A.; Barhanpurkar, A.P.; et al. Miro1 Regulates Intercellular Mitochondrial Transport \& Enhances Mesenchymal Stem Cell Rescue Efficacy. EMBO J. 2014, 33, 994-1010. [CrossRef] [PubMed]

122. Turturici, G.; Tinnirello, R.; Sconzo, G.; Geraci, F. Extracellular Membrane Vesicles as a Mechanism of Cell-to-cell Communication: Advantages and Disadvantages. Am. J. Physiol. Cell Physiol. 2014, 306, C621-C633. [CrossRef] [PubMed]

123. Al-Nedawi, K.; Meehan, B.; Rak, J. Microvesicles: Messengers and Mediators of Tumor Progression. Cell Cycle 2009, 8, 2014-2018. [CrossRef] [PubMed]

124. Mathivanan, S.; Ji, H.; Simpson, R.J. Exosomes: Extracellular Organelles Important in Intercellular Communication. J. Proteomics 2010, 73, 1907-1920. [CrossRef]

125. Al-Nedawi, K.; Meehan, B.; Micallef, J.; Lhotak, V.; May, L.; Guha, A.; Rak, J. Intercellular Transfer of the Oncogenic Receptor EGFRvIII by Microvesicles Derived from Tumour Cells. Nat. Cell Biol. 2008, 10, 619-624. [CrossRef] [PubMed]

126. Lou, E.; Fujisawa, S.; Morozov, A.; Barlas, A.; Romin, Y.; Dogan, Y.; Gholami, S.; Moreira, A.L.; Manova-Todorova, K.; Moore, M.A.S. Tunneling Nanotubes Provide a Unique Conduit for Intercellular Transfer of Cellular Contents in Human Malignant Pleural Mesothelioma. PLoS ONE 2012, 7, e33093. [CrossRef]

127. Thayanithy, V.; Babatunde, V.; Dickson, E.L.; Wong, P.; Oh, S.; Ke, X.; Barlas, A.; Fujisawa, S.; Romin, Y.; Moreira, A.L.; et al. Tumor Exosomes Induce Tunneling Nanotubes in Lipid Raft-enriched Regions of Human Mesothelioma Cells. Exp. Cell Res. 2014, 323, 178-188. [CrossRef] [PubMed] 
128. Pasquier, J.; Guerrouahen, B.S.; Al Thawadi, H.; Ghiabi, P.; Maleki, M.; Abu-Kaoud, N.; Jacob, A.; Mirshahi, M.; Galas, L.; Rafii, S.; et al. Preferential Transfer of Mitochondria from Endothelial to Cancer Cells through Tunneling Nanotubes Modulates Chemoresistance. J. Transl. Med. 2013, 11, 94. [CrossRef]

129. Lou, E.; Fujisawa, S.; Barlas, A.; Romin, Y.; Manova-Todorova, K.; Moore, M.A.S.; Subramanian, S. Tunneling Nanotubes: A New Paradigm for Studying Intercellular Communication and Therapeutics in Cancer. Commun. Integr. Biol. 2012, 5, 399-403. [CrossRef]

130. Lu, J.; Zheng, X.; Li, F.; Yu, Y.; Chen, Z.; Liu, Z.; Wang, Z.; Xu, H.; Yang, W. Tunneling Nanotubes Promote Intercellular Mitochondria Transfer Followed by Increased Invasiveness in Bladder Cancer Cells. Oncotarget 2017, 8, 15539-15552. [CrossRef]

131. Spees, J.L.; Olson, S.D.; Whitney, M.J.; Prockop, D.J. Mitochondrial Transfer between Cells Can Rescue Aerobic Respiration. Proc. Natl. Acad. Sci. USA 2006, 103, 1283-1288. [CrossRef]

132. Caicedo, A.; Fritz, V.; Brondello, J.-M.; Ayala, M.; Dennemont, I.; Abdellaoui, N.; de Fraipont, F.; Moisan, A.; Prouteau, C.A.; Boukhaddaoui, H.; et al. MitoCeption as a New Tool to Assess the Effects of Mesenchymal Stem/Stromal Cell Mitochondria on Cancer Cell Metabolism and Function. Sci. Rep. 2015, 5, 9073. [CrossRef] [PubMed]

133. Tan, A.S.; Baty, J.W.; Dong, L.-F.; Bezawork-Geleta, A.; Endaya, B.; Goodwin, J.; Bajzikova, M.; Kovarova, J.; Peterka, M.; Yan, B.; et al. Mitochondrial Genome Acquisition Restores Respiratory Function and Tumorigenic Potential of Cancer Cells without Mitochondrial DNA. Cell Metab. 2015, 21, 81-94. [CrossRef]

134. Patheja, P.; Sahu, K. Macrophage Conditioned Medium Induced Cellular Network Formation in MCF-7 Cells through Enhanced Tunneling Nanotube Formation and Tunneling Nanotube Mediated Release of Viable Cytoplasmic Fragments. Exp. Cell Res. 2017, 355, 182-193. [CrossRef]

135. Moschoi, R.; Imbert, V.; Nebout, M.; Chiche, J.; Mary, D.; Prebet, T.; Saland, E.; Castellano, R.; Pouyet, L.; Collette, Y.; et al. Protective Mitochondrial Transfer from Bone Marrow Stromal Cells to Acute Myeloid Leukemic Cells during Chemotherapy. Blood 2016, 128, 253-264. [CrossRef]

136. Marlein, C.R.; Zaitseva, L.; Piddock, R.E.; Robinson, S.D.; Edwards, D.R.; Shafat, M.S.; Zhou, Z.; Lawes, M.; Bowles, K.M.; Rushworth, S.A. NADPH Oxidase-2 Derived Superoxide Drives Mitochondrial Transfer from Bone Marrow Stromal Cells to Leukemic Blasts. Blood 2017, 130, 1649-1660. [CrossRef]

137. Salaud, C.; Alvarez-Arenas, A.; Geraldo, F.; Belmonte-Beitia, J.; Calvo, G.F.; Gratas, C.; Pecqueur, C.; Garnier, D.; Pérez-Garcià, V.; Vallette, F.M.; et al. Mitochondria Transfer from Tumor-activated Stromal Cells (TASC) to Primary Glioblastoma Cells. Biochem. Biophys. Res. Commun. 2020, 533, 139-147. [CrossRef]

138. Wang, J.; Liu, X.; Qiu, Y.; Shi, Y.; Cai, J.; Wang, B.; Wei, X.; Ke, Q.; Sui, X.; Wang, Y.; et al. Cell Adhesion-mediated Mitochondria Transfer Contributes to Mesenchymal Stem Cell-induced Chemoresistance on T Cell Acute Lymphoblastic Leukemia Cells. J. Hematol. Oncol. 2018, 11, 11. [CrossRef] [PubMed]

139. Boukelmoune, N.; Chiu, G.S.; Kavelaars, A.; Heijnen, C.J. Mitochondrial Transfer from Mesenchymal Stem Cells to Neural Stem Cells Protects against the Neurotoxic Effects of Cisplatin. Acta Neuropathol. Commun. 2018, 6, 139. [CrossRef] [PubMed]

140. Sansone, P.; Savini, C.; Kurelac, I.; Chang, Q.; Amato, L.B.; Strillacci, A.; Stepanova, A.; Iommarini, L.; Mastroleo, C.; Daly, L.; et al. Packaging and Transfer of Mitochondrial DNA via Exosomes Regulate Escape from Dormancy in Hormonal Therapy-resistant Breast Cancer. Proc. Natl. Acad. Sci. USA 2017, 114, E9066-E9075. [CrossRef] [PubMed]

141. Bong, A.H.L.; Monteith, G.R. Calcium Signaling and the Therapeutic Targeting of Cancer Cells. Biochim. Biophys. Acta Mol. Cell Res. 2018, 1865, 1786-1794. [CrossRef] [PubMed]

142. Raffaello, A.; Mammucari, C.; Gherardi, G.; Rizzuto, R. Calcium at the Center of Cell Signaling: Interplay between Endoplasmic Reticulum, Mitochondria, and Lysosomes. Trends Biochem. Sci. 2016, 41, 1035-1049. [CrossRef] [PubMed]

143. Sterea, A.M.; El Hiani, Y. The Role of Mitochondrial Calcium Signaling in the Pathophysiology of Cancer Cells. Adv. Exp. Med. Biol. 2020, 1131, 747-770. [CrossRef] [PubMed]

144. Giorgi, C.; Marchi, S.; Pinton, P. Publisher Correction: The Machineries, Regulation and Cellular Functions of Mitochondrial Calcium. Nat. Rev. Mol. Cell Biol. 2018, 19, 746. [CrossRef]

145. Giorgi, C.; Wieckowski, M.R.; Pandolfi, P.P.; Pinton, P. Mitochondria Associated Membranes (MAMs) as Critical Hubs for Apoptosis. Commun. Integr. Biol. 2011, 4, 334-335. [CrossRef] [PubMed]

146. Patergnani, S.; Suski, J.M.; Agnoletto, C.; Bononi, A.; Bonora, M.; De Marchi, E.; Giorgi, C.; Marchi, S.; Missiroli, S.; Poletti, F.; et al. Calcium Signaling around Mitochondria Associated Membranes (MAMs). Cell Commun. Signal. 2011, 9, 19. [CrossRef]

147. Bononi, A.; Missiroli, S.; Poletti, F.; Suski, J.M.; Agnoletto, C.; Bonora, M.; De Marchi, E.; Giorgi, C.; Marchi, S.; Patergnani, S.; et al. Mitochondria-associated Membranes (MAMs) as Hotspot Ca(2+) Signaling Units. Adv. Exp. Med. Biol. 2012, 740, $411-437$. [CrossRef]

148. Bononi, A.; Bonora, M.; Marchi, S.; Missiroli, S.; Poletti, F.; Giorgi, C.; Pandolfi, P.P.; Pinton, P. Identification of PTEN at the ER and MAMs and Its Regulation of $\mathrm{Ca}(2+)$ Signaling and Apoptosis in a Protein Phosphatase-dependent Manner. Cell Death Differ. 2013, 20, 1631-1643. [CrossRef]

149. Marchi, S.; Giorgi, C.; Oparka, M.; Duszynski, J.; Wieckowski, M.R.; Pinton, P. Oncogenic and Oncosuppressive Signal Transduction at Mitochondria-associated Endoplasmic Reticulum Membranes. Mol. Cell. Oncol. 2014, 1, e956469. [CrossRef]

150. Giorgi, C.; Missiroli, S.; Patergnani, S.; Duszynski, J.; Wieckowski, M.R.; Pinton, P. Mitochondria-associated Membranes: Composition, Molecular Mechanisms, and Physiopathological Implications. Antioxid. Redox Signal. 2015, 22, 995-1019. [CrossRef] 
151. Danese, A.; Patergnani, S.; Bonora, M.; Wieckowski, M.R.; Previati, M.; Giorgi, C.; Pinton, P. Calcium Regulates Cell Death in Cancer: Roles of the Mitochondria and Mitochondria-associated Membranes (MAMs). Biochim. Biophys. Acta Bioenergy 2017, 1858, 615-627. [CrossRef] [PubMed]

152. Marchi, S.; Bittremieux, M.; Missiroli, S.; Morganti, C.; Patergnani, S.; Sbano, L.; Rimessi, A.; Kerkhofs, M.; Parys, J.B.; Bultynck, G.; et al. Endoplasmic Reticulum-Mitochondria Communication Through $\mathrm{Ca}^{2+}$ Signaling: The Importance of MitochondriaAssociated Membranes (MAMs). Adv. Exp. Med. Biol. 2017, 997, 49-67. [CrossRef] [PubMed]

153. Pinton, P. Mitochondria-associated Membranes (MAMs) and Pathologies. Cell Death Dis. 2018, 9, 413. [CrossRef] [PubMed]

154. Marchi, S.; Patergnani, S.; Pinton, P. The Endoplasmic Reticulum-mitochondria Connection: One Touch, Multiple Functions. Biochim. Biophys. Acta Bioenergy 2014, 1837, 461-469. [CrossRef]

155. Wyrsch, P.; Blenn, C.; Pesch, T.; Beneke, S.; Althaus, F.R. Cytosolic Ca ${ }^{2+}$ Shifts as Early Markers of Cytotoxicity. Cell Commun. Signal 2013, 11, 11. [CrossRef]

156. Kerkhofs, M.; Bittremieux, M.; Morciano, G.; Giorgi, C.; Pinton, P.; Parys, J.B.; Bultynck, G. Emerging Molecular Mechanisms in Chemotherapy: $\mathrm{Ca}^{2+}$ Signaling at the Mitochondria-associated Endoplasmic Reticulum Membranes. Cell Death Dis. 2018, 9, 334. [CrossRef]

157. Rimessi, A.; Patergnani, S.; Bonora, M.; Wieckowski, M.R.; Pinton, P. Mitochondrial Ca(2+) Remodeling is a Prime Factor in Oncogenic Behavior. Front. Oncol. 2015, 5, 143. [CrossRef]

158. Patergnani, S.; Giorgi, C.; Maniero, S.; Missiroli, S.; Maniscalco, P.; Bononi, I.; Martini, F.; Cavallesco, G.; Tognon, M.; Pinton, P. The Endoplasmic Reticulum Mitochondrial Calcium Cross Talk is Downregulated in Malignant Pleural Mesothelioma Cells and Plays a Critical Role in Apoptosis Inhibition. Oncotarget 2015, 6, 23427-23444. [CrossRef]

159. Büsselberg, D.; Florea, A.-M. Targeting Intracellular Calcium Signaling $\left(\left[\mathrm{Ca}^{2+}\right] \mathrm{i}\right)$ to Overcome Acquired Multidrug Resistance of Cancer Cells: A Mini-Overview. Cancers 2017, 9, 48. [CrossRef]

160. Santoni, G.; Morelli, M.B.; Marinelli, O.; Nabissi, M.; Santoni, M.; Amantini, C. Calcium Signaling and the Regulation of Chemosensitivity in Cancer Cells: Role of the Transient Receptor Potential Channels. Adv. Exp. Med. Biol. 2020, 1131, 505-517. [CrossRef]

161. Cui, C.; Merritt, R.; Fu, L.; Pan, Z. Targeting Calcium Signaling in Cancer Therapy. Acta Pharm. Sin. B 2017, 7, 3-17. [CrossRef] [PubMed]

162. Lee, J.M.; Davis, F.M.; Roberts-Thomson, S.J.; Monteith, G.R. Ion Channels and Transporters in Cancer. 4. Remodeling of Ca(2+) Signaling in Tumorigenesis: Role of Ca(2+) Transport. Am. J. Physiol. Cell Physiol. 2011, 301, C969-C976. [CrossRef]

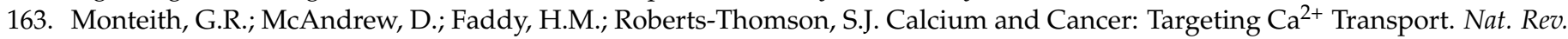
Cancer 2007, 7, 519-530. [CrossRef] [PubMed]

164. Monteith, G.R.; Davis, F.M.; Roberts-Thomson, S.J. Calcium Channels and Pumps in Cancer: Changes and Consequences. J. Biol. Chem. 2012, 287, 31666-31673. [CrossRef]

165. Cmoch, A.; Groves, P.; Palczewska, M.; Pikuła, S. S100A Proteins in Propagation of a Calcium Signal in Norm and Pathology. Postepy Biochem. 2012, 58, 429-436. [PubMed]

166. Chen, Y.-F.; Chen, Y.-T.; Chiu, W.-T.; Shen, M.-R. Remodeling of Calcium Signaling in Tumor Progression. J. Biomed. Sci. 2013, 20, 23. [CrossRef]

167. Peruzzo, R.; Szabo, I. Contribution of Mitochondrial Ion Channels to Chemo-Resistance in Cancer Cells. Cancers 2019, 11, 761. [CrossRef]

168. Szabo, I.; Zoratti, M. Mitochondrial Channels: Ion Fluxes and More. Physiol. Rev. 2014, 94, 519-608. [CrossRef]

169. Laskowski, M.; Augustynek, B.; Kulawiak, B.; Koprowski, P.; Bednarczyk, P.; Jarmuszkiewicz, W.; Szewczyk, A. What Do We not Know about Mitochondrial Potassium Channels? Biochim. Biophys. Acta 2016, 1857, 1247-1257. [CrossRef]

170. Marchi, S.; Pinton, P. The Mitochondrial Calcium Uniporter Complex: Molecular Components, Structure and Physiopathological Implications. J. Physiol. 2014, 592, 829-839. [CrossRef]

171. Baughman, J.M.; Perocchi, F.; Girgis, H.S.; Plovanich, M.; Belcher-Timme, C.A.; Sancak, Y.; Bao, X.R.; Strittmatter, L.; Goldberger, O.; Bogorad, R.L.; et al. Integrative Genomics Identifies MCU as an Essential Component of the Mitochondrial Calcium Uniporter. Nature 2011, 476, 341-345. [CrossRef] [PubMed]

172. Mallilankaraman, K.; Doonan, P.; Cárdenas, C.; Chandramoorthy, H.C.; Müller, M.; Miller, R.; Hoffman, N.E.; Gandhirajan, R.K.; Molgó, J.; Birnbaum, M.J.; et al. MICU1 is an Essential Gatekeeper for MCU-mediated Mitochondrial Ca(2+) Uptake That Regulates Cell Survival. Cell 2012, 151, 630-644. [CrossRef] [PubMed]

173. Patron, M.; Checchetto, V.; Raffaello, A.; Teardo, E.; Vecellio Reane, D.; Mantoan, M.; Granatiero, V.; Szabò, I.; De Stefani, D.; Rizzuto, R. MICU1 and MICU2 Finely Tune the Mitochondrial $\mathrm{Ca}^{2+}$ Uniporter by Exerting Opposite Effects on MCU Activity. Mol. Cell 2014, 53, 726-737. [CrossRef]

174. Sancak, Y.; Markhard, A.L.; Kitami, T.; Kovács-Bogdán, E.; Kamer, K.J.; Udeshi, N.D.; Carr, S.A.; Chaudhuri, D.; Clapham, D.E.; Li, A.A.; et al. EMRE is an Essential Component of the Mitochondrial Calcium Uniporter Complex. Science 2013, 342, 1379-1382. [CrossRef] [PubMed]

175. Raffaello, A.; De Stefani, D.; Sabbadin, D.; Teardo, E.; Merli, G.; Picard, A.; Checchetto, V.; Moro, S.; Szabò, I.; Rizzuto, R. The Mitochondrial Calcium Uniporter is a Multimer That Can Include a Dominant-negative Pore-forming Subunit. EMBO J. 2013, 32, 2362-2376. [CrossRef] [PubMed]

176. Foskett, J.K.; Philipson, B. The Mitochondrial Ca(2+) Uniporter Complex. J. Mol. Cell. Cardiol. 2015, 78, 3-8. [CrossRef] 
177. Bonora, M.; Wieckowski, M.R.; Chinopoulos, C.; Kepp, O.; Kroemer, G.; Galluzzi, L.; Pinton, P. Molecular Mechanisms of Cell Death: Central Implication of ATP Synthase in Mitochondrial Permeability Transition. Oncogene 2015, 34, 1475-1486. [CrossRef] [PubMed]

178. De Stefani, D.; Raffaello, A.; Teardo, E.; Szabò, I.; Rizzuto, R. A Forty-kilodalton Protein of the Inner Membrane is the Mitochondrial Calcium Uniporter. Nature 2011, 476, 336-340. [CrossRef] [PubMed]

179. Marchi, S.; Lupini, L.; Patergnani, S.; Rimessi, A.; Missiroli, S.; Bonora, M.; Bononi, A.; Corrà, F.; Giorgi, C.; De Marchi, E.; et al Downregulation of the Mitochondrial Calcium Uniporter by Cancer-related miR-25. Curr. Biol. 2013, 23, 58-63. [CrossRef] [PubMed]

180. Marchi, S.; Pinton, P. Mitochondrial Calcium Uniporter, MiRNA and Cancer: Live and Let Die. Commun. Integr. Biol. 2013, 6, e23818. [CrossRef]

181. Zeng, F.; Chen, X.; Cui, W.; Wen, W.; Lu, F.; Sun, X.; Ma, D.; Yuan, Y.; Li, Z.; Hou, N.; et al. RIPK1 Binds MCU to Mediate Induction of Mitochondrial Ca ${ }^{2+}$ Uptake and Promotes Colorectal Oncogenesis. Cancer Res. 2018, 78, 2876-2885. [CrossRef]

182. Ren, T.; Wang, J.; Zhang, H.; Yuan, P.; Zhu, J.; Wu, Y.; Huang, Q.; Guo, X.; Zhang, J.; Ji, L.; et al. MCUR1-Mediated Mitochondrial Calcium Signaling Facilitates Cell Survival of Hepatocellular Carcinoma via Reactive Oxygen Species-Dependent P53 Degradation. Antioxid. Redox Signal. 2018, 28, 1120-1136. [CrossRef]

183. Hall, D.D.; Wu, Y.; Domann, F.E.; Spitz, D.R.; Anderson, M.E. Mitochondrial Calcium Uniporter Activity is Dispensable for MDA-MB-231 Breast Carcinoma Cell Survival. PLoS ONE 2014, 9, e96866. [CrossRef] [PubMed]

184. Chen, L.; Sun, Q.; Zhou, D.; Song, W.; Yang, Q.; Ju, B.; Zhang, L.; Xie, H.; Zhou, L.; Hu, Z.; et al. HINT2 Triggers Mitochondrial $\mathrm{Ca}^{2+}$ Influx by Regulating the Mitochondrial $\mathrm{Ca}^{2+}$ Uniporter (MCU) Complex and Enhances Gemcitabine Apoptotic Effect in Pancreatic Cancer. Cancer Lett. 2017, 411, 106-116. [CrossRef] [PubMed]

185. Antony, A.N.; Paillard, M.; Moffat, C.; Juskeviciute, E.; Correnti, J.; Bolon, B.; Rubin, E.; Csordás, G.; Seifert, E.L.; Hoek, J.B.; et al MICU1 Regulation of Mitochondrial Ca(2+) Uptake Dictates Survival and Tissue Regeneration. Nat. Commun. 2016, 7, 10955. [CrossRef] [PubMed]

186. Rao, G.; Dwivedi, S.K.D.; Zhang, Y.; Dey, A.; Shameer, K.; Karthik, R.; Srikantan, S.; Hossen, M.N.; Wren, J.D.; Madesh, M.; et al. MicroRNA-195 Controls MICU1 Expression and Tumor Growth in Ovarian Cancer. EMBO Rep. 2020, 21, e48483. [CrossRef] [PubMed]

187. Leanza, L.; Checchetto, V.; Biasutto, L.; Rossa, A.; Costa, R.; Bachmann, M.; Zoratti, M.; Szabo, I. Pharmacological Modulation of Mitochondrial Ion Channels. Br. J. Pharmacol. 2019, 176, 4258-4283. [CrossRef]

188. Vultur, A.; Gibhardt, C.S.; Stanisz, H.; Bogeski, I. The Role of the Mitochondrial Calcium Uniporter (MCU) Complex in Cancer. Pflugers Arch. 2018, 470, 1149-1163. [CrossRef]

189. Cui, C.; Yang, J.; Fu, L.; Wang, M.; Wang, X. Progress in Understanding Mitochondrial Calcium Uniporter Complex-mediated Calcium Signalling: A Potential Target for Cancer Treatment. Br. J. Pharmacol. 2019, 176, 1190-1205. [CrossRef]

190. Messina, A.; Reina, S.; Guarino, F.; De Pinto, V. VDAC Isoforms in Mammals. Biochim. Biophys. Acta 2012, $1818,1466-1476$. [CrossRef]

191. Shoshan-Barmatz, V.; De Pinto, V.; Zweckstetter, M.; Raviv, Z.; Keinan, N.; Arbel, N. VDAC, a Multi-functional Mitochondrial Protein Regulating Cell Life and Death. Mol. Aspects Med. 2010, 31, 227-285. [CrossRef]

192. Shoshan-Barmatz, V.; Ben-Hail, D.; Admoni, L.; Krelin, Y.; Tripathi, S.S. The Mitochondrial Voltage-dependent Anion Channel 1 in Tumor Cells. Biochim. Biophys. Acta 2015, 1848, 2547-2575. [CrossRef]

193. Martel, C.; Wang, Z.; Brenner, C. VDAC Phosphorylation, a Lipid Sensor Influencing the Cell Fate. Mitochondrion 2014, 19 Pt A, 69-77. [CrossRef]

194. Shoshan-Barmatz, V.; Krelin, Y.; Chen, Q. VDAC1 as a Player in Mitochondria-Mediated Apoptosis and Target for Modulating Apoptosis. Curr. Med. Chem. 2017, 24, 4435-4446. [CrossRef] [PubMed]

195. Gogvadze, V.; Zhivotovsky, B.; Orrenius, S. The Warburg Effect and Mitochondrial Stability in Cancer Cells. Mol. Aspects Med. 2010, 31, 60-74. [CrossRef]

196. Hockenbery, D.M. Targeting Mitochondria for Cancer Therapy. Environ. Mol. Mutagen. 2010, 51, 476-489. [CrossRef] [PubMed]

197. Fulda, S.; Kroemer, G. Mitochondria as Therapeutic Targets for the Treatment of Malignant Disease. Antioxid. Redox Signal. 2011, 15, 2937-2949. [CrossRef] [PubMed]

198. Pahima, H.; Reina, S.; Tadmor, N.; Dadon-Klein, D.; Shteinfer-Kuzmine, A.; Mazure, N.M.; De Pinto, V.; Shoshan-Barmatz, V. Hypoxic-induced Truncation of Voltage-dependent Anion Channel 1 is Mediated by Both Asparagine Endopeptidase and Calpain 1 Activities. Oncotarget 2018, 9, 12825-12841. [CrossRef]

199. Brahimi-Horn, M.C.; Ben-Hail, D.; Ilie, M.; Gounon, P.; Rouleau, M.; Hofman, V.; Doyen, J.; Mari, B.; Shoshan-Barmatz, V.; Hofman, P.; et al. Expression of a Truncated Active form of VDAC1 in Lung Cancer Associates with Hypoxic Cell Survival and Correlates with Progression to Chemotherapy Resistance. Cancer Res. 2012, 72, 2140-2150. [CrossRef]

200. Ferecatu, I.; Canal, F.; Fabbri, L.; Mazure, N.M.; Bouton, C.; Golinelli-Cohen, M.-P. Dysfunction in the Mitochondrial Fe-S Assembly Machinery Leads to Formation of the Chemoresistant Truncated VDAC1 Isoform without HIF-1 $\alpha$ Activation. PLoS ONE 2018, 13, e0194782. [CrossRef]

201. Dehghan-Nayeri, N.; Rezaei-Tavirani, M.; Omrani, M.D.; Gharehbaghian, A.; Goudarzi Pour, K.; Eshghi, P. Identification of Potential Predictive Markers of Dexamethasone Resistance in Childhood Acute Lymphoblastic Leukemia. J. Cell Commun. Signal. 2017, 11, 137-145. [CrossRef] [PubMed] 
202. Sotgia, F.; Fiorillo, M.; Lisanti, M.P. Mitochondrial Markers Predict Recurrence, Metastasis and Tamoxifen-resistance in Breast Cancer Patients: Early Detection of Treatment Failure with Companion Diagnostics. Oncotarget 2017, 8, 68730-68745. [CrossRef] [PubMed]

203. Arbel, N.; Shoshan-Barmatz, V. Voltage-dependent Anion Channel 1-based Peptides Interact with Bcl-2 to Prevent Antiapoptotic Activity. J. Biol. Chem. 2010, 285, 6053-6062. [CrossRef] [PubMed]

204. Prezma, T.; Shteinfer, A.; Admoni, L.; Raviv, Z.; Sela, I.; Levi, I.; Shoshan-Barmatz, V. VDAC1-based Peptides: Novel Pro-apoptotic Agents and Potential Therapeutics for B-cell Chronic Lymphocytic Leukemia. Cell Death Dis. 2013, 4, e809. [CrossRef] [PubMed]

205. Shteinfer-Kuzmine, A.; Amsalem, Z.; Arif, T.; Zooravlov, A.; Shoshan-Barmatz, V. Selective Induction of Cancer Cell Death by VDAC1-based Peptides and Their Potential Use in Cancer Therapy. Mol. Oncol. 2018, 12, 1077-1103. [CrossRef] [PubMed]

206. Pittala, S.; Krelin, Y.; Shoshan-Barmatz, V. Targeting Liver Cancer and Associated Pathologies in Mice with a Mitochondrial VDAC1-Based Peptide. Neoplasia 2018, 20, 594-609. [CrossRef]

207. Magrì, A.; Reina, S.; De Pinto, V. VDAC1 as Pharmacological Target in Cancer and Neurodegeneration: Focus on Its Role in Apoptosis. Front. Chem. 2018, 6, 108. [CrossRef]

208. Palty, R.; Silverman, W.F.; Hershfinkel, M.; Caporale, T.; Sensi, S.L.; Parnis, J.; Nolte, C.; Fishman, D.; Shoshan-Barmatz, V.; Herrmann, S.; et al. NCLX is an Essential Component of Mitochondrial Na+/Ca ${ }^{2+}$ Exchange. Proc. Natl. Acad. Sci. USA 2010, 107, 436-441. [CrossRef]

209. Ben-Kasus Nissim, T.; Zhang, X.; Elazar, A.; Roy, S.; Stolwijk, J.A.; Zhou, Y.; Motiani, R.K.; Gueguinou, M.; Hempel, N.; Hershfinkel, M.; et al. Mitochondria Control Store-operated $\mathrm{Ca}^{2+}$ Entry through Na+ and Redox Signals. EMBO J. 2017, 36, 797-815. [CrossRef]

210. Pathak, T.; Gueguinou, M.; Walter, V.; Delierneux, C.; Johnson, M.T.; Zhang, X.; Xin, P.; Yoast, R.E.; Emrich, S.M.; Yochum, G.S.; et al. Dichotomous Role of the Human Mitochondrial $\mathrm{Na}+/ \mathrm{Ca}^{2+} / \mathrm{Li}+$ Exchanger NCLX in Colorectal Cancer Growth and Metastasis. Elife 2020, 9. [CrossRef]

211. Perrone, M.; Caroccia, N.; Genovese, I.; Missiroli, S.; Modesti, L.; Pedriali, G.; Vezzani, B.; Vitto, V.A.M.; Antenori, M.; Lebiedzinska-Arciszewska, M.; et al. The Role of Mitochondria-associated Membranes in Cellular Homeostasis and Diseases. Int. Rev. Cell Mol. Biol. 2020, 350, 119-196. [CrossRef]

212. Pruenster, M.; Vogl, T.; Roth, J.; Sperandio, M. S100A8/A9: From Basic Science to Clinical Application. Pharmacol. Ther. 2016, 167, 120-131. [CrossRef]

213. Wang, S.; Song, R.; Wang, Z.; Jing, Z.; Wang, S.; Ma, J. S100A8/A9 in Inflammation. Front. Immunol. 2018, 9, 1298. [CrossRef] [PubMed]

214. Shabani, F.; Farasat, A.; Mahdavi, M.; Gheibi, N. Calprotectin (S100A8/S100A9): A Key Protein between Inflammation and Cancer. Inflamm. Res. 2018, 67, 801-812. [CrossRef]

215. Yang, M.; Zeng, P.; Kang, R.; Yu, Y.; Yang, L.; Tang, D.; Cao, L. S100A8 Contributes to Drug Resistance by Promoting Autophagy in Leukemia Cells. PLoS ONE 2014, 9, e97242. [CrossRef] [PubMed]

216. Yang, L.; Yang, M.; Zhang, H.; Wang, Z.; Yu, Y.; Xie, M.; Zhao, M.; Liu, L.; Cao, L. S100A8-targeting siRNA Enhances Arsenic Trioxide-induced Myeloid Leukemia Cell Death by Down-regulating Autophagy. Int. J. Mol. Med. 2012, 29, 65-72. [CrossRef] [PubMed]

217. Ghavami, S.; Eshragi, M.; Ande, S.R.; Chazin, W.J.; Klonisch, T.; Halayko, A.J.; McNeill, K.D.; Hashemi, M.; Kerkhoff, C.; Los, M. S100A8/A9 Induces Autophagy and Apoptosis via ROS-mediated Cross-talk between Mitochondria and Lysosomes That Involves BNIP3. Cell Res. 2010, 20, 314-331. [CrossRef] [PubMed]

218. Yang, J.; Anholts, J.; Kolbe, U.; Stegehuis-Kamp, J.A.; Claas, F.H.J.; Eikmans, M. Calcium-Binding Proteins S100A8 and S100A9: Investigation of Their Immune Regulatory Effect in Myeloid Cells. Int. J. Mol. Sci. 2018, 19, 1833. [CrossRef] [PubMed]

219. Li, X.; Zhou, Y.; Li, Y.; Yang, L.; Ma, Y.; Peng, X.; Yang, S.; Liu, J.; Li, H. Autophagy: A Novel Mechanism of Chemoresistance in Cancers. Biomed. Pharmacother. 2019, 119, 109415. [CrossRef]

220. Piya, S.; Andreeff, M.; Borthakur, G. Targeting Autophagy to Overcome Chemoresistance in Acute Myleogenous Leukemia. Autophagy 2017, 13, 214-215. [CrossRef]

221. Levy, J.M.M.; Towers, C.G.; Thorburn, A. Targeting Autophagy in Cancer. Nat. Rev. Cancer 2017, 17, 528-542. [CrossRef] [PubMed]

222. Onorati, A.V.; Dyczynski, M.; Ojha, R.; Amaravadi, R.K. Targeting Autophagy in Cancer. Cancer 2018, 124, 3307-3318. [CrossRef]

223. Zhang, L.; Zhou, S.; Zhou, T.; Yuan, K.; Li, X.; Tang, J. S100A8 Promotes Chemoresistance via Augmenting Autophagy in B-cell Lymphoma Cells. Oncol. Rep. 2021, 45, 151-158. [CrossRef] [PubMed]

224. Chourasia, A.H.; Macleod, K.F. Tumor Suppressor Functions of BNIP3 and Mitophagy. Autophagy 2015, 11, 1937-1938. [CrossRef] [PubMed]

225. Dhingra, A.; Jayas, R.; Afshar, P.; Guberman, M.; Maddaford, G.; Gerstein, J.; Lieberman, B.; Nepon, H.; Margulets, V.; Dhingra, R.; et al. Ellagic Acid Antagonizes Bnip3-mediated Mitochondrial Injury and Necrotic Cell Death of Cardiac Myocytes. Free Radic. Biol. Med. 2017, 112, 411-422. [CrossRef]

226. Ma, Z.; Chen, C.; Tang, P.; Zhang, H.; Yue, J.; Yu, Z. BNIP3 Induces Apoptosis and Protective Autophagy under Hypoxia in Esophageal Squamous Cell Carcinoma Cell Lines: BNIP3 Regulates Cell Death. Dis. Esophagus 2017, 30, 1-8. [CrossRef]

227. Zhang, L.; Li, L.; Leavesley, H.W.; Zhang, X.; Borowitz, J.L.; Isom, G.E. Cyanide-induced Apoptosis of Dopaminergic Cells is Promoted by BNIP3 and Bax Modulation of Endoplasmic Reticulum-mitochondrial Ca ${ }^{2+}$ Levels. J. Pharmacol. Exp. Ther. 2010, 332, 97-105. [CrossRef] 
228. Farrell, E.F.; Antaramian, A.; Rueda, A.; Gómez, A.M.; Valdivia, H.H. Sorcin Inhibits Calcium Release and Modulates Excitationcontraction Coupling in the Heart. J. Biol. Chem. 2003, 278, 34660-34666. [CrossRef] [PubMed]

229. Meyers, M.B.; Fischer, A.; Sun, Y.-J.; Lopes, C.M.B.; Rohacs, T.; Nakamura, T.Y.; Zhou, Y.-Y.; Lee, P.C.; Altschuld, R.A.; McCune, S.A.; et al. Sorcin Regulates Excitation-contraction Coupling in the Heart. J. Biol. Chem. 2003, 278, 28865-28871. [CrossRef]

230. Matsumoto, T.; Hisamatsu, Y.; Ohkusa, T.; Inoue, N.; Sato, T.; Suzuki, S.; Ikeda, Y.; Matsuzaki, M. Sorcin Interacts with Sarcoplasmic Reticulum Ca(2+)-ATPase and Modulates Excitation-contraction Coupling in the Heart. Basic Res. Cardiol. 2005, 100, 250-262. [CrossRef]

231. Meyers, M.B.; Puri, T.S.; Chien, A.J.; Gao, T.; Hsu, P.H.; Hosey, M.M.; Fishman, G.I. Sorcin Associates with the Pore-forming Subunit of Voltage-dependent L-type $\mathrm{Ca}^{2+}$ Channels. J. Biol. Chem. 1998, 273, 18930-18935. [CrossRef] [PubMed]

232. Lokuta, A.J.; Meyers, M.B.; Sander, P.R.; Fishman, G.I.; Valdivia, H.H. Modulation of Cardiac Ryanodine Receptors by Sorcin. J. Biol. Chem. 1997, 272, 25333-25338. [CrossRef]

233. Zamparelli, C.; Macquaide, N.; Colotti, G.; Verzili, D.; Seidler, T.; Smith, G.L.; Chiancone, E. Activation of the Cardiac Na(+)-Ca(2+) Exchanger by Sorcin via the Interaction of the Respective Ca(2+)-binding Domains. J. Mol. Cell. Cardiol. 2010, 49, 132-141. [CrossRef] [PubMed]

234. Suarez, J.; McDonough, P.M.; Scott, B.T.; Suarez-Ramirez, A.; Wang, H.; Fricovsky, E.S.; Dillmann, W.H. Sorcin Modulates Mitochondrial $\mathrm{Ca}(2+)$ Handling and Reduces Apoptosis in Neonatal Rat Cardiac Myocytes. Am. J. Physiol. Cell Physiol. 2013, 304, C248-C256. [CrossRef] [PubMed]

235. Van der Bliek, A.M.; Meyers, M.B.; Biedler, J.L.; Hes, E.; Borst, P. A 22-kd Protein (Sorcin/V19) Encoded by an Amplified Gene in Multidrug-resistant Cells, is Homologous to the Calcium-binding Light Chain of Calpain. EMBO J. 1986, 5, 3201-3208. [CrossRef] [PubMed]

236. Meyers, M.B.; Schneider, K.A.; Spengler, B.A.; Chang, T.D.; Biedler, J.L. Sorcin (V19), a Soluble Acidic Calcium-binding Protein Overproduced in Multidrug-resistant Cells. Identification of the Protein by Anti-sorcin Antibody. Biochem. Pharmacol. 1987, 36, 2373-2380. [CrossRef]

237. Van der Bliek, A.M.; Baas, F.; Van der Velde-Koerts, T.; Biedler, J.L.; Meyers, M.B.; Ozols, R.F.; Hamilton, T.C.; Joenje, H.; Borst, P. Genes Amplified and Overexpressed in Human Multidrug-resistant Cell Lines. Cancer Res. 1988, 48, 5927-5932.

238. Colotti, G.; Poser, E.; Fiorillo, A.; Genovese, I.; Chiarini, V.; Ilari, A. Sorcin, a Calcium Binding Protein Involved in the Multidrug Resistance Mechanisms in Cancer Cells. Molecules 2014, 19, 13976-13989. [CrossRef]

239. Yang, Y.-X.; Chen, Z.-C.; Zhang, G.-Y.; Yi, H.; Xiao, Z.-Q. A Subcelluar Proteomic Investigation into Vincristine-resistant Gastric Cancer Cell Line. J. Cell. Biochem. 2008, 104, 1010-1021. [CrossRef] [PubMed]

240. Battista, T.; Fiorillo, A.; Chiarini, V.; Genovese, I.; Ilari, A.; Colotti, G. Roles of Sorcin in Drug Resistance in Cancer: One Protein, Many Mechanisms, for a Novel Potential Anticancer Drug Target. Cancers 2020, 12, 887. [CrossRef] [PubMed]

241. Genovese, I.; Ilari, A.; Assaraf, Y.G.; Fazi, F.; Colotti, G. Not only P-glycoprotein: Amplification of the ABCB1-containing Chromosome Region 7q21 Confers Multidrug Resistance upon Cancer Cells by Coordinated Overexpression of an Assortment of Resistance-related Proteins. Drug Resist. Updat. 2017, 32, 23-46. [CrossRef]

242. Li, G.; Tan, Y.; Yang, C.; Zhao, C.; Zhao, H.; Wang, J.; Xue, Y.; Han, M.; Qian, L.; Zhao, C. Expression and Clinical Implication of Soluble Resistance-associated Calcium-binding Protein Gene and Multi-drug Resistance Gene in Leukemia. Zhonghua Zhong Liu Za Zhi 2002, 24, 370-374. [PubMed]

243. Demidova, N.S.; Ilyinskaya, G.V.; Shiryaeva, O.A.; Chernova, O.B.; Goncharova, S.A.; Kopnin, B.P. Decreased Sensitivity of Multidrug-resistant Tumor Cells to Cisplatin is Correlated with Sorcin Gene Co-amplification. Neoplasma 1995, 42, 195-201. [PubMed]

244. Yamagishi, N.; Nakao, R.; Kondo, R.; Nishitsuji, M.; Saito, Y.; Kuga, T.; Hatayama, T.; Nakayama, Y. Increased Expression of Sorcin is Associated with Multidrug Resistance in Leukemia Cells via Up-regulation of MDR1 Expression through cAMP Response Element-binding Protein. Biochem. Biophys. Res. Commun. 2014, 448, 430-436. [CrossRef] [PubMed]

245. He, Q.; Zhang, G.; Hou, D.; Leng, A.; Xu, M.; Peng, J.; Liu, T. Overexpression of Sorcin Results in Multidrug Resistance in Gastric Cancer Cells with Up-regulation of P-gp. Oncol. Rep. 2011, 25, 237-243. [PubMed]

246. Tan, Y.; Li, G.; Zhao, C.; Wang, J.; Zhao, H.; Xue, Y.; Han, M.; Yang, C. Expression of Sorcin Predicts Poor Outcome in Acute Myeloid Leukemia. Leuk. Res. 2003, 27, 125-131. [CrossRef]

247. Zhou, Y.; Xu, Y.; Tan, Y.; Qi, J.; Xiao, Y.; Yang, C.; Zhu, Z.; Xiong, D. Sorcin, an Important Gene Associated with Multidrugresistance in Human Leukemia Cells. Leuk. Res. 2006, 30, 469-476. [CrossRef]

248. Liu, X.; Chen, L.; Feng, B.; Liu, G. Reversing Effect of Sorcin in the Drug Resistance of Human Nasopharyngeal Carcinoma. Anat. Rec. 2014, 297, 215-221. [CrossRef]

249. Hu, Y.; Cheng, X.; Li, S.; Zhou, Y.; Wang, J.; Cheng, T.; Yang, M.; Xiong, D. Inhibition of Sorcin Reverses Multidrug Resistance of K562/A02 Cells and MCF-7/A02 Cells via Regulating Apoptosis-related Proteins. Cancer Chemother. Pharmacol. 2013, 72, 789-798. [CrossRef]

250. Maddalena, F.; Laudiero, G.; Piscazzi, A.; Secondo, A.; Scorziello, A.; Lombardi, V.; Matassa, D.S.; Fersini, A.; Neri, V.; Esposito, F.; et al. Sorcin Induces a Drug-resistant Phenotype in Human Colorectal Cancer by Modulating Ca(2+) Homeostasis. Cancer Res. 2011, 71, 7659-7669. [CrossRef]

251. Gong, Z.; Sun, P.; Chu, H.; Zhu, H.; Sun, D.; Chen, J. Overexpression of Sorcin in Multidrug-resistant Human Breast Cancer. Oncol. Lett. 2014, 8, 2393-2398. [CrossRef] [PubMed] 
252. Hu, Y.; Li, S.; Yang, M.; Yan, C.; Fan, D.; Zhou, Y.; Zhang, Y.; Yagüe, E.; Xiong, D. Sorcin Silencing Inhibits Epithelial-tomesenchymal Transition and Suppresses Breast Cancer Metastasis in vivo. Breast Cancer Res. Treat. 2014, 143, 287-299. [CrossRef] [PubMed]

253. Parekh, H.K.; Deng, H.B.; Choudhary, K.; Houser, S.R.; Simpkins, H. Overexpression of Sorcin, a Calcium-binding Protein, Induces a Low Level of Paclitaxel Resistance in Human Ovarian and Breast Cancer Cells. Biochem. Pharmacol. 2002, 63, 1149-1158 [CrossRef]

254. Genovese, I.; Fiorillo, A.; Ilari, A.; Masciarelli, S.; Fazi, F.; Colotti, G. Binding of Doxorubicin to Sorcin Impairs Cell Death and Increases Drug Resistance in Cancer Cells. Cell Death Dis. 2017, 8, e2950. [CrossRef]

255. Landriscina, M.; Laudiero, G.; Maddalena, F.; Amoroso, M.R.; Piscazzi, A.; Cozzolino, F.; Monti, M.; Garbi, C.; Fersini, A.; Pucci, P.; et al. Mitochondrial Chaperone Trap1 and the Calcium Binding Protein Sorcin Interact and Protect Cells Against Apoptosis Induced by Antiblastic Agents. Cancer Res. 2010, 70, 6577-6586. [CrossRef] [PubMed]

256. Maddalena, F.; Sisinni, L.; Lettini, G.; Condelli, V.; Matassa, D.S.; Piscazzi, A.; Amoroso, M.R.; La Torre, G.; Esposito, F.; Landriscina, M. Resistance to Paclitxel in Breast Carcinoma Cells Requires a Quality Control of Mitochondrial Antiapoptotic Proteins by TRAP1. Mol. Oncol. 2013, 7, 895-906. [CrossRef]

257. Genovese, I.; Giamogante, F.; Barazzuol, L.; Battista, T.; Fiorillo, A.; Vicario, M.; D’Alessandro, G.; Cipriani, R.; Limatola, C.; Rossi, D.; et al. Sorcin is an Early Marker of Neurodegeneration, $\mathrm{Ca}^{2+}$ Dysregulation and Endoplasmic Reticulum Stress Associated to Neurodegenerative Diseases. Cell Death Dis. 2020, 11, 861. [CrossRef] [PubMed]

258. Mellor, H.; Parker, P.J. The Extended Protein Kinase C Superfamily. Biochem. J. 1998, 332, 281-292. [CrossRef] [PubMed]

259. Dekker, L.V.; Parker, P.J. Protein Kinase C-a Question of Specificity. Trends Biochem. Sci. 1994, 19, 73-77. [CrossRef]

260. Toker, A. Signaling through Protein Kinase C. Front. Biosci. 1998, 3, 1134-1147. [CrossRef] [PubMed]

261. Nishizuka, Y. Intracellular Signaling by Hydrolysis of Phospholipids and Activation of Protein Kinase C. Science 1992, 258, 607-614. [CrossRef] [PubMed]

262. Oancea, E.; Meyer, T. Protein Kinase C as a Molecular Machine for Decoding Calcium and Diacylglycerol Signals. Cell 1998, 95 , 307-318. [CrossRef]

263. Montero, M.; Lobatón, C.D.; Gutierrez-Fernández, S.; Moreno, A.; Alvarez, J. Modulation of Histamine-induced Ca ${ }^{2+}$ Release by Protein Kinase C. Effects on Cytosolic and Mitochondrial [Ca $\left.{ }^{2+}\right]$ Peaks. J. Biol. Chem. 2003, 278, 49972-49979. [CrossRef] [PubMed]

264. Berra, E.; Diaz-Meco, M.T.; Dominguez, I.; Municio, M.M.; Sanz, L.; Lozano, J.; Chapkin, R.S.; Moscat, J. Protein Kinase C Zeta Isoform is Critical for Mitogenic Signal Transduction. Cell 1993, 74, 555-563. [CrossRef]

265. Cohen, E.E.W.; Lingen, M.W.; Zhu, B.; Zhu, H.; Straza, M.W.; Pierce, C.; Martin, L.E.; Rosner, M.R. Protein Kinase C Zeta Mediates Epidermal Growth Factor-induced Growth of Head and Neck Tumor Cells by Regulating Mitogen-activated Protein Kinase. Cancer Res. 2006, 66, 6296-6303. [CrossRef] [PubMed]

266. Kampfer, S.; Windegger, M.; Hochholdinger, F.; Schwaiger, W.; Pestell, R.G.; Baier, G.; Grunicke, H.H.; Uberall, F. Protein Kinase C Isoforms Involved in the Transcriptional Activation of Cyclin D1 by Transforming Ha-Ras. J. Biol. Chem. 2001, 276, 42834-42842. [CrossRef]

267. Leroy, I.; de Thonel, A.; Laurent, G.; Quillet-Mary, A. Protein Kinase C Zeta Associates with Death Inducing Signaling Complex and Regulates Fas Ligand-induced Apoptosis. Cell. Signal. 2005, 17, 1149-1157. [CrossRef]

268. Moscat, J.; Rennert, P.; Diaz-Meco, M.T. PKCzeta at the Crossroad of NF-kappaB and Jak1/Stat6 Signaling Pathways. Cell Death Differ. 2006, 13, 702-711. [CrossRef]

269. Bezombes, C.; de Thonel, A.; Apostolou, A.; Louat, T.; Jaffrézou, J.-P.; Laurent, G.; Quillet-Mary, A. Overexpression of Protein Kinase Czeta Confers Protection against Antileukemic Drugs by Inhibiting the Redox-dependent Sphingomyelinase Activation Mol. Pharmacol. 2002, 62, 1446-1455. [CrossRef]

270. Filomenko, R.; Poirson-Bichat, F.; Billerey, C.; Belon, J.-P.; Garrido, C.; Solary, E.; Bettaieb, A. Atypical Protein Kinase C Zeta as a Target for Chemosensitization of Tumor Cells. Cancer Res. 2002, 62, 1815-1821.

271. Rimessi, A.; Patergnani, S.; Ioannidi, E.; Pinton, P. Chemoresistance and Cancer-Related Inflammation: Two Hallmarks of Cancer

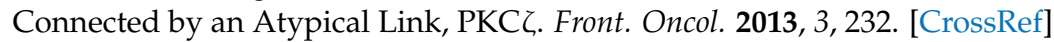

272. Rimessi, A.; Zecchini, E.; Siviero, R.; Giorgi, C.; Leo, S.; Rizzuto, R.; Pinton, P. The Selective Inhibition of Nuclear PKC $\zeta$ Restores the Effectiveness of Chemotherapeutic Agents in Chemoresistant Cells. Cell Cycle 2012, 11, 1040-1048. [CrossRef]

273. Pinton, P.; Leo, S.; Wieckowski, M.R.; Di Benedetto, G.; Rizzuto, R. Long-term Modulation of Mitochondrial Ca ${ }^{2+}$ Signals by Protein Kinase C Isozymes. J. Cell Biol. 2004, 165, 223-232. [CrossRef] [PubMed]

274. Gerschman, R.; Gilbert, D.L.; Nye, S.W.; Dwyer, P.; Fenn, W.O. Oxygen Poisoning and X-irradiation: A Mechanism in Common. Science 1954, 119, 623-626. [CrossRef] [PubMed]

275. Sena, L.A.; Chandel, N.S. Physiological Roles of Mitochondrial Reactive Oxygen Species. Mol. Cell 2012, 48, 158-167. [CrossRef] [PubMed]

276. Holmström, K.M.; Finkel, T. Cellular Mechanisms and Physiological Consequences of Redox-dependent Signalling. Nat. Rev. Mol. Cell Biol. 2014, 15, 411-421. [CrossRef] [PubMed]

277. Dan Dunn, J.; Alvarez, L.A.; Zhang, X.; Soldati, T. Reactive Oxygen Species and Mitochondria: A Nexus of Cellular Homeostasis. Redox Biol. 2015, 6, 472-485. [CrossRef] [PubMed] 
278. Ziech, D.; Franco, R.; Pappa, A.; Panayiotidis, M.I. Reactive Oxygen Species (ROS)-Induced Genetic and Epigenetic Alterations in Human Carcinogenesis. Mutat. Res. 2011, 711, 167-173. [CrossRef]

279. He, L.; He, T.; Farrar, S.; Ji, L.; Liu, T.; Ma, X. Antioxidants Maintain Cellular Redox Homeostasis by Elimination of Reactive Oxygen Species. Cell. Physiol. Biochem. 2017, 44, 532-553. [CrossRef]

280. Cao, L.; Xu, X.; Cao, L.L.; Wang, R.-H.; Coumoul, X.; Kim, S.S.; Deng, C.-X. Absence of Full-length Brca1 Sensitizes Mice to Oxidative Stress and Carcinogen-induced Tumorigenesis in the Esophagus and Forestomach. Carcinogenesis 2007, 28, 1401-1407. [CrossRef]

281. Weinberg, F.; Hamanaka, R.; Wheaton, W.W.; Weinberg, S.; Joseph, J.; Lopez, M.; Kalyanaraman, B.; Mutlu, G.M.; Budinger, G.R.S.; Chandel, N.S. Mitochondrial Metabolism and ROS Generation are Essential for Kras-mediated Tumorigenicity. Proc. Natl. Acad. Sci. USA 2010, 107, 8788-8793. [CrossRef]

282. Vafa, O.; Wade, M.; Kern, S.; Beeche, M.; Pandita, T.K.; Hampton, G.M.; Wahl, G.M. c-Myc Can Induce DNA Damage, Increase Reactive Oxygen Species, and Mitigate p53 Function: A Mechanism for Oncogene-induced Genetic Instability. Mol. Cell 2002, 9, 1031-1044. [CrossRef]

283. Tanaka, H.; Matsumura, I.; Ezoe, S.; Satoh, Y.; Sakamaki, T.; Albanese, C.; Machii, T.; Pestell, R.G.; Kanakura, Y. E2F1 and c-Myc Potentiate Apoptosis through Inhibition of NF-kappaB Activity That Facilitates MnSOD-mediated ROS Elimination. Mol. Cell 2002, 9, 1017-1029. [CrossRef]

284. Aggarwal, V.; Tuli, H.S.; Varol, A.; Thakral, F.; Yerer, M.B.; Sak, K.; Varol, M.; Jain, A.; Khan, M.A.; Sethi, G. Role of Reactive Oxygen Species in Cancer Progression: Molecular Mechanisms and Recent Advancements. Biomolecules 2019, 9, 735. [CrossRef]

285. Nishikawa, M. Reactive Oxygen Species in Tumor Metastasis. Cancer Lett. 2008, 266, 53-59. [CrossRef] [PubMed]

286. Liao, Z.; Chua, D.; Tan, N.S. Reactive Oxygen Species: A Volatile Driver of Field Cancerization and Metastasis. Mol. Cancer 2019, 18, 65. [CrossRef]

287. Yang, H.; Villani, R.M.; Wang, H.; Simpson, M.J.; Roberts, M.S.; Tang, M.; Liang, X. The Role of Cellular Reactive Oxygen Species in Cancer Chemotherapy. J. Exp. Clin. Cancer Res. 2018, 37, 266. [CrossRef]

288. Wang, J.; Yi, J. Cancer Cell Killing via ROS: To Increase or Decrease, That is the Question. Cancer Biol. Ther. 2008, 7, 1875-1884. [CrossRef]

289. Conklin, K.A. Chemotherapy-associated Oxidative Stress: Impact on Chemotherapeutic Effectiveness. Integr. Cancer Ther. 2004, 3, 294-300. [CrossRef]

290. Mizutani, H.; Tada-Oikawa, S.; Hiraku, Y.; Kojima, M.; Kawanishi, S. Mechanism of Apoptosis Induced by Doxorubicin through the Generation of Hydrogen Peroxide. Life Sci. 2005, 76, 1439-1453. [CrossRef]

291. Wang, H.; Li, X.; Chen, T.; Wang, W.; Liu, Q.; Li, H.; Yi, J.; Wang, J. Mechanisms of Verapamil-enhanced Chemosensitivity of Gallbladder Cancer Cells to Platinum Drugs: Glutathione Reduction and MRP1 Downregulation. Oncol. Rep. 2013, 29, 676-684. [CrossRef]

292. Li, X.; Dong, Y.; Wang, W.; Wang, H.; Chen, Y.; Shi, G.; Yi, J.; Wang, J. Emodin as an Effective Agent in Targeting Cancer Stem-like Side Population Cells of Gallbladder Carcinoma. Stem Cells Dev. 2013, 22, 554-566. [CrossRef]

293. Li, X.; Wang, H.; Wang, J.; Chen, Y.; Yin, X.; Shi, G.; Li, H.; Hu, Z.; Liang, X. Emodin Enhances Cisplatin-induced Cytotoxicity in Human Bladder Cancer Cells through ROS Elevation and MRP1 Downregulation. BMC Cancer 2016, 16, 578. [CrossRef] [PubMed]

294. Shi, H.; Shi, X.; Liu, K.J. Oxidative Mechanism of Arsenic Toxicity and Carcinogenesis. Mol. Cell. Biochem. 2004, 255, 67-78. [CrossRef] [PubMed]

295. Yen, Y.-P.; Tsai, K.-S.; Chen, Y.-W.; Huang, C.-F.; Yang, R.-S.; Liu, S.-H. Arsenic Induces Apoptosis in Myoblasts through a Reactive Oxygen Species-induced Endoplasmic Reticulum Stress and Mitochondrial Dysfunction Pathway. Arch. Toxicol. 2012, 86, 923-933. [CrossRef]

296. Dragovich, T.; Gordon, M.; Mendelson, D.; Wong, L.; Modiano, M.; Chow, H.-H.S.; Samulitis, B.; O’Day, S.; Grenier, K.; Hersh, E.; et al. Phase I Trial of Imexon in Patients with Advanced Malignancy. J. Clin. Oncol. 2007, 25, 1779-1784. [CrossRef] [PubMed]

297. Engel, R.H.; Evens, A.M. Oxidative Stress and Apoptosis: A New Treatment Paradigm in Cancer. Front. Biosci. 2006, 11, 300-312. [CrossRef] [PubMed]

298. Alexandre, J.; Nicco, C.; Chéreau, C.; Laurent, A.; Weill, B.; Goldwasser, F.; Batteux, F. Improvement of the Therapeutic Index of Anticancer Drugs by the Superoxide Dismutase Mimic Mangafodipir. J. Natl. Cancer Inst. 2006, 98, 236-244. [CrossRef] [PubMed]

299. Rowe, L.A.; Degtyareva, N.; Doetsch, P.W. DNA Damage-induced Reactive Oxygen Species (ROS) Stress Response in Saccharomyces cerevisiae. Free Radic. Biol. Med. 2008, 45, 1167-1177. [CrossRef]

300. Marullo, R.; Werner, E.; Degtyareva, N.; Moore, B.; Altavilla, G.; Ramalingam, S.S.; Doetsch, P.W. Cisplatin Induces a Mitochondrial-ROS Response That Contributes to Cytotoxicity Depending on Mitochondrial Redox Status and Bioenergetic Functions. PLoS ONE 2013, 8, e81162. [CrossRef] [PubMed]

301. de Sá Junior, P.L.; Câmara, D.A.D.; Porcacchia, A.S.; Fonseca, P.M.M.; Jorge, S.D.; Araldi, R.P.; Ferreira, A.K. The Roles of ROS in Cancer Heterogeneity and Therapy. Oxid. Med. Cell. Longev. 2017, 2017, 2467940. [CrossRef] [PubMed]

302. Maiti, A.K. Gene Network Analysis of Oxidative Stress-mediated Drug Sensitivity in Resistant Ovarian Carcinoma Cells. Pharm. J. 2010, 10, 94-104. [CrossRef] [PubMed]

303. Desbats, M.A.; Giacomini, I.; Prayer-Galetti, T.; Montopoli, M. Metabolic Plasticity in Chemotherapy Resistance. Front. Oncol. 2020, 10, 281. [CrossRef] [PubMed] 
304. Ledoux, S.; Yang, R.; Friedlander, G.; Laouari, D. Glucose Depletion Enhances P-glycoprotein Expression in Hepatoma Cells: Role of Endoplasmic Reticulum Stress Response. Cancer Res. 2003, 63, 7284-7290.

305. Cheng, S.C.-S.; Zhou, J.; Xie, Y. P-glycoprotein Expression Induced by Glucose Depletion Enhanced the Chemosensitivity in Human Hepatocellular Carcinoma Cell-lines. Cell Biol. Int. 2005, 29, 269-275. [CrossRef]

306. Chen, J.; Adikari, M.; Pallai, R.; Parekh, H.K.; Simpkins, H. Dihydrodiol Dehydrogenases Regulate the Generation of Reactive Oxygen Species and the Development of Cisplatin Resistance in Human Ovarian Carcinoma Cells. Cancer Chemother. Pharmacol. 2008, 61, 979-987. [CrossRef]

307. Jimenez-Del-Rio, M.; Velez-Pardo, C. The Bad, the Good, and the Ugly about Oxidative Stress. Oxid. Med. Cell. Longev. 2012, 2012, 163913. [CrossRef] [PubMed]

308. Chan, S.M.; Majeti, R. Role of DNMT3A, TET2, and IDH1/2 Mutations in Pre-leukemic Stem Cells in Acute Myeloid Leukemia. Int. J. Hematol. 2013, 98, 648-657. [CrossRef]

309. Al-Hajj, M.; Wicha, M.S.; Benito-Hernandez, A.; Morrison, S.J.; Clarke, M.F. Prospective Identification of Tumorigenic Breast Cancer Cells. Proc. Natl. Acad. Sci. USA 2003, 100, 3983-3988. [CrossRef]

310. Hermann, P.C.; Huber, S.L.; Herrler, T.; Aicher, A.; Ellwart, J.W.; Guba, M.; Bruns, C.J.; Heeschen, C. Distinct Populations of Cancer Stem Cells Determine Tumor Growth and Metastatic Activity in Human Pancreatic Cancer. Cell Stem Cell 2007, 1, 313-323. [CrossRef]

311. Ding, S.; Li, C.; Cheng, N.; Cui, X.; Xu, X.; Zhou, G. Redox Regulation in Cancer Stem Cells. Oxid. Med. Cell. Longev. 2015, 2015, 750798. [CrossRef] [PubMed]

312. Diehn, M.; Cho, R.W.; Lobo, N.A.; Kalisky, T.; Dorie, M.J.; Kulp, A.N.; Qian, D.; Lam, J.S.; Ailles, L.E.; Wong, M.; et al. Association of Reactive Oxygen Species Levels and Radioresistance in Cancer Stem Cells. Nature 2009, 458, 780-783. [CrossRef] [PubMed]

313. Phillips, T.M.; McBride, W.H.; Pajonk, F. The Response of CD24(-/low)/CD44+ Breast Cancer-initiating Cells to Radiation. J. Natl. Cancer Inst. 2006, 98, 1777-1785. [CrossRef] [PubMed]

314. Hanahan, D.; Weinberg, R.A. Hallmarks of Cancer: The Next Generation. Cell 2011, 144, 646-674. [CrossRef]

315. Guerra, F.; Arbini, A.A.; Moro, L. Mitochondria and Cancer Chemoresistance. Biochim. Biophys. Acta Bioenergy 2017, $1858,686-699$. [CrossRef]

316. Krall, A.S.; Christofk, H.R. Rethinking Glutamine Addiction. Nat. Cell Biol. 2015, 17, 1515-1517. [CrossRef]

317. Son, J.; Lyssiotis, C.A.; Ying, H.; Wang, X.; Hua, S.; Ligorio, M.; Perera, R.M.; Ferrone, C.R.; Mullarky, E.; Shyh-Chang, N.; et al. Glutamine Supports Pancreatic Cancer Growth through a KRAS-regulated Metabolic Pathway. Nature 2013, 496, $101-105$. [CrossRef]

318. Warburg, O. On the Origin of Cancer Cells. Science 1956, 123, 309-314. [CrossRef] [PubMed]

319. Cannino, G.; Ciscato, F.; Masgras, I.; Sánchez-Martín, C.; Rasola, A. Metabolic Plasticity of Tumor Cell Mitochondria. Front. Oncol. 2018, 8, 333. [CrossRef]

320. Gentric, G.; Kieffer, Y.; Mieulet, V.; Goundiam, O.; Bonneau, C.; Nemati, F.; Hurbain, I.; Raposo, G.; Popova, T.; Stern, M.-H.; et al. PML-Regulated Mitochondrial Metabolism Enhances Chemosensitivity in Human Ovarian Cancers. Cell Metab. 2019, 29, 156-173.e10. [CrossRef]

321. Matassa, D.S.; Amoroso, M.R.; Lu, H.; Avolio, R.; Arzeni, D.; Procaccini, C.; Faicchia, D.; Maddalena, F.; Simeon, V.; Agliarulo, I.; et al. Oxidative Metabolism Drives Inflammation-induced Platinum Resistance in Human Ovarian Cancer. Cell Death Differ. 2016, 23, 1542-1554. [CrossRef]

322. Amoroso, M.R.; Matassa, D.S.; Agliarulo, I.; Avolio, R.; Maddalena, F.; Condelli, V.; Landriscina, M.; Esposito, F. Stress-Adaptive Response in Ovarian Cancer Drug Resistance: Role of TRAP1 in Oxidative Metabolism-Driven Inflammation. Adv. Protein Chem. Struct. Biol. 2017, 108, 163-198. [CrossRef]

323. Chakraborty, P.K.; Mustafi, S.B.; Xiong, X.; Dwivedi, S.K.D.; Nesin, V.; Saha, S.; Zhang, M.; Dhanasekaran, D.; Jayaraman, M.; Mannel, R.; et al. MICU1 Drives Glycolysis and Chemoresistance in Ovarian Cancer. Nat. Commun. 2017, 8, 14634. [CrossRef]

324. Lim, J.-H.; Luo, C.; Vazquez, F.; Puigserver, P. Targeting Mitochondrial Oxidative Metabolism in Melanoma Causes Metabolic Compensation through Glucose and Glutamine Utilization. Cancer Res. 2014, 74, 3535-3545. [CrossRef] [PubMed]

325. Sun, Y.; Xu, H.; Chen, X.; Li, X.; Luo, B. Inhibition of Mitochondrial Respiration Overcomes Hepatocellular Carcinoma Chemoresistance. Biochem. Biophys. Res. Commun. 2019, 508, 626-632. [CrossRef] [PubMed]

326. Viale, A.; Pettazzoni, P.; Lyssiotis, C.A.; Ying, H.; Sánchez, N.; Marchesini, M.; Carugo, A.; Green, T.; Seth, S.; Giuliani, V.; et al. Oncogene Ablation-resistant Pancreatic Cancer Cells Depend on Mitochondrial Function. Nature 2014, 514, 628-632. [CrossRef] [PubMed]

327. Vellinga, T.T.; Borovski, T.; de Boer, V.C.J.; Fatrai, S.; van Schelven, S.; Trumpi, K.; Verheem, A.; Snoeren, N.; Emmink, B.L.; Koster, J.; et al. SIRT1/PGC1 $\alpha$-Dependent Increase in Oxidative Phosphorylation Supports Chemotherapy Resistance of Colon Cancer. Clin. Cancer Res. 2015, 21, 2870-2879. [CrossRef] [PubMed] 